\title{
Modifying a dynamic global vegetation model for simulating large spatial scale land surface water balances
}

\author{
G. Tang $^{1}$ and P. J. Bartlein ${ }^{2}$ \\ ${ }^{1}$ Division of Earth and Ecosystem Sciences, Desert Research Institute, Reno, NV 89512, USA \\ ${ }^{2}$ Department of Geography, University of Oregon, Eugene, OR 97403, USA
}

Correspondence to: G. Tang (tangg2010@gmail.com)

Received: 13 November 2011 - Published in Hydrol. Earth Syst. Sci. Discuss.: 23 January 2012

Revised: 27 June 2012 - Accepted: 8 July 2012 - Published: 7 August 2012

\begin{abstract}
Satellite-based data, such as vegetation type and fractional vegetation cover, are widely used in hydrologic models to prescribe the vegetation state in a study region. Dynamic global vegetation models (DGVM) simulate land surface hydrology. Incorporation of satellite-based data into a DGVM may enhance a model's ability to simulate land surface hydrology by reducing the task of model parameterization and providing distributed information on land characteristics. The objectives of this study are to (i) modify a DGVM for simulating land surface water balances; (ii) evaluate the modified model in simulating actual evapotranspiration (ET), soil moisture, and surface runoff at regional or watershed scales; and (iii) gain insight into the ability of both the original and modified model to simulate large spatial scale land surface hydrology. To achieve these objectives, we introduce the "LPJ-hydrology" (LH) model which incorporates satellite-based data into the Lund-Potsdam-Jena (LPJ) DGVM. To evaluate the model we ran LH using historical (1981-2006) climate data and satellite-based land covers at 2.5 arc-min grid cells for the conterminous US and for the entire world using coarser climate and land cover data. We evaluated the simulated ET, soil moisture, and surface runoff using a set of observed or simulated data at different spatial scales. Our results demonstrate that spatial patterns of LH-simulated annual ET and surface runoff are in accordance with previously published data for the US; LHmodeled monthly stream flow for 12 major rivers in the US was consistent with observed values respectively during the years 1981-2006 $\left(R^{2}>0.46, p<0.01\right.$; Nash-Sutcliffe Coefficient $>0.52)$. The modeled mean annual discharges for 10 major rivers worldwide also agreed well (differences $<15 \%$ ) with observed values for these rivers. Compared to
\end{abstract}

a degree-day method for snowmelt computation, the addition of the solar radiation effect on snowmelt enabled $\mathrm{LH}$ to better simulate monthly stream flow in winter and early spring for rivers located at mid-to-high latitudes. In addition, LH-modeled monthly soil moisture for the state of Illinois (US) agreed well $\left(R^{2}=0.79, p<0.01\right)$ with observed data for the years 1984-2001. Overall, this study justifies both the feasibility of incorporating satellite-based land covers into a DGVM and the reliability of LH to simulate land-surface water balances. To better estimate surface/river runoff at mid-tohigh latitudes, we recommended that LPJ-DGVM considers the effects of solar radiation on snowmelt.

\section{Introduction}

Evapotranspiration (ET), soil moisture, and surface runoff are three major components of the hydrologic cycle at the land surface, and affect many important processes in the soil-vegetation-atmosphere system (Lu et al., 2003; Murphy and Lodge, 2004). For example, changes in actual and potential ET have implications for nutrient flux, forest function, plant productivity (e.g. Kosugi and Katsuyama, 2007), and the global carbon cycle (Engstrom et al., 2006). Soil moisture can influence near-surface atmospheric variability (Arora and Boer, 2006) and atmospheric circulation on seasonal-to-interannual time scales (Shukla and Mintz, 1982; Manabe and Delworth, 1990). Soil-moisture deficits can also restrict the respiration and the productivity of plants, and thus influence species composition as well as type and structure of vegetation (Evans and Trevisan, 1995; Brabson et al., 2005). Shifts in surface runoff influence the ability of regional water 
supply and demand as well as the cycling of nutrients globally. The importance of ET, soil moisture, and surface runoff for human well-being, terrestrial ecosystems, and agricultural sustainability requires that we be able to simulate landsurface water balances, especially given that the global hydrological cycle is expected to intensify in response to ongoing climate change (e.g. Murray et al., 2011).

Dynamic global vegetation models (DGVM) - such as the Lund-Potsdam-Jena (LPJ) DGVM (Sitch et al., 2003; Gerten et al., 2004), LPJmL (e.g. Müller et al., 2006; Rost et al., 2008), and LPX (e.g. Murray et al., 2011) - that also simulate hydrology have illustrated a general ability to simulate land surface water balances at the global scale. Nevertheless, hydrological evaluations of DGVMs at the global scale have suggested that improvements are still needed for DGVMs to more accurately simulate land surface water balances. For example, Gerten et al. (2004) suggested that LPJ-DGVM tended to underestimate surface runoff at high latitudes in the Northern Hemisphere. In addition, DGVMs focus mainly on biogeographic and biogeochemical dynamics of terrestrial vegetation. The application of a DGVM requires users to define and parameterize the bioclimatic, biogeochemical, and physiological attributes of plants. Parameterization of model parameters is always challenging and affects the reliability of model results (e.g. Zaehle et al., 2005; Wramneby et al., 2008; Brovkin et al., 2012). Generalization of plants into a few functional types in DGVMs may not be adequate to represent the true variation of land-cover characteristics, which in turn could affect the accuracy of modeled water flux dynamics among soil, vegetation, and the atmosphere. The inadequacy of water routing among simulated units also challenges DGVM's ability to simulate the timing and convergence of surface water in rivers (e.g. Döll et al., 2003; Murray et al., 2011). Nevertheless, DGVMs integrate roles of climate variation, vegetation, soil features, and atmospheric composition (i.e. $\mathrm{CO}_{2}$ ) in controlling ET, soil moisture, and runoff at the land surface. Because DGVMs specifically simulate processes like the non-water-stressed stomatal control of plant transpiration and the effects of changes in $\mathrm{CO}_{2}$ concentration on plant water use efficiency, they offer distinct advantages in modeling the role of vegetation in the landsurface water balance under various global-change scenarios (e.g. Milly and Shmakin, 2002; Betts et al., 2007).

Satellite data provide distributed information about hydrological surface states and the parameters needed for calibration and evaluation of water-balance models (Campo et al., 2006). Compared to traditional land-cover data, satellite data are often at higher spatial and temporal resolutions (O'Donnell et al., 2000). In fact, satellite-based data are widely used in hydrologic models to predefine land characteristics in a study region or obtain necessary information about vegetation parameters (e.g. Glenn et al., 2007; Montzka et al., 2008; Khan et al., 2011). To simulate land surface hydrology, incorporation of satellite-based data into a DGVM would thus have the following advantages: (i) to help simplify model structure by making the explicit representation of mechanistic processes, such as plant growth, carbon allocation, and soil respiration, unnecessary when satellite-based data are available (e.g. leaf area index); (ii) to reduce model parameterization associated with plant bioclimatic, biogeochemical, and physiological attributes; and (iii) to contribute to the reliability of model results because satellite data are generally thought to be of high spatial accuracy in representing land characteristics. Montzka et al. (2008) found that the introduction of satellite-based land cover can enhance the reliability of water-balance models and produce thematically more accurate and spatially more detailed local water balances. Boegh et al. (2004) suggested that the distributed information from satellite data on land use and vegetation parameters is significant for the correct prediction of the ET rate and soil-water balance.

The objectives of this study were to (i) modify LPJDGVM (Sitch et al., 2003; Gerten et al., 2004) for simulating regional scale land surface water balances under satellite-specified land cover; (ii) evaluate the application of this model, named LH (LPJ-hydrology), in the conterminous US and elsewhere; and (iii) gain insight into improving both LH's and LPJ-DGVM's performance in modeling landsurface water balances. We selected the US as a study region because it has relatively rich data required for model evaluation. Given that LPJ-DGVM was originally developed for simulating global-scale vegetation and hydrology, we also ran LH globally to further evaluate its reliability.

The following paper is organized into five sections: Sect. 2 introduces the LH model including calculation and parameterization of vegetation and soil water balance in LH; Sect. 3 introduces data used to run and evaluate LH's performance at different spatial scales; Sect. 4 describes model results and evaluation at different spatial scales; Sect. 5 discusses model results and the potential insights obtained from this study; and Sect. 6 summarizes main findings from this study.

\section{Methodology}

\subsection{The LH model}

The stand-alone LH (LPJ-hydrology) model was developed by modifying LPJ-DGVM (Sitch et al., 2003; Gerten et al., 2004) and shares many of the original features. In general, LH consists of the following three main sub-models: (i) a potential-ET model that calculates pseudo-daily photosynthetic active radiation flux, day length, and daily equilibrium potential ET in each grid cell using climate data and latitude; (ii) a summer phenology model that evaluates daily leaf phenology for predefined land covers; and (iii) a water-balance model coupled with plant photosynthesis that simulates major components of water balance including soil evaporation, plant transpiration, soil moisture, and surface runoff (Fig. 1). 


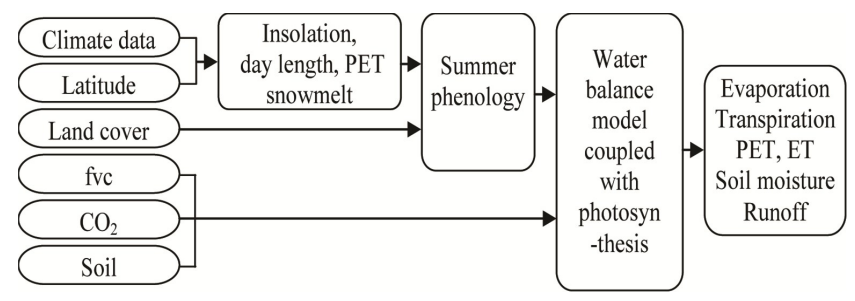

Fig. 1. A flowchart that describes the LH (LPJ-hydrology) model for calculating several hydrologic variables using climate, land cover, foliar vegetative cover (fvc), $\mathrm{CO}_{2}$ and soil data. PET and ET are short for potential and actual evapotranspiration, respectively.

The input land cover data in LH is used (i) to initialize some hydrologic and photosynthetic relevant parameters (Tables 1 and 2), (ii) to define phenological features of each predefined land cover as one of four types (i.e. evergreen, summer green, rain green and other), and (iii) to specify the photosynthetic pathway of plants (i.e. C4 vs. C3). Foliar vegetative cover (fvc) is used to calculate plant-specific minimum canopy conductance and the total amount of interception loss of precipitation by plants. In this study, we assign land cover in the conterminous US and worldwide to 11 types respectively based on global land cover classification data (Hansen et al., 2000). Five types are forest (two evergreen, two deciduous and one mixed forest) and six are non-forest (one woodland, one shrubland, one grassland, one cropland, one bare and one urban) (Table 1). For each land cover type, the fractional fvc in a cell varies from 0 to 1 .

In addition to vegetation-related data, other data needed to run $\mathrm{LH}$ include monthly mean temperature $\left({ }^{\circ} \mathrm{C}\right)$, precipitation $(\mathrm{mm})$, wet-day frequency (days), and percent cloudiness or sunshine (\%), as well as annual atmospheric $\mathrm{CO}_{2}$ concentration. The monthly time-step input climate data were linearly interpolated into quasi daily values as in LPJDGVM. The $\mathrm{CO}_{2}$ data are used to calculate non-waterstressed canopy conductance and intercellular $\mathrm{CO}_{2}$ partial pressure (Haxeltine and Prentice, 1996). The soil data used in LH still consists of two layers with a fixed thickness (upper, $50 \mathrm{~cm}$; lower, $100 \mathrm{~cm}$ ). To better initialize some important variables such as soil moisture content and fraction of available water in two soil layers, the first year's simulation in LH was run twice. The one year spin-up simulation was sufficient to correctly simulate land-surface water balances for the first year because vegetation-related biogeochemical processes are excluded in LH. Soil moisture of each layer is updated at a daily time-step on the basis of the previous day's soil moisture by balancing the amount of water infiltrating into soil with that removed from two soil layers through runoff, percolation, and actual ET.

\subsection{Vegetation water balance in $\mathrm{LH}$}

The land-cover-related parameters (or attributes) in LH can be classified into two categories: (i) parameters that govern dynamics of water balance in the soil-vegetation-atmosphere systems (Table 1); and (ii) parameters that are necessary for simulating plant photosynthesis (Table 2). The first category involves leaf longevity (LeL), the fraction of roots in two soil layers $\left(f_{1}\right.$ and $\left.f_{2}\right)$, the minimum water scalar value $\left(W_{\min }\right)$ at which leaves are shed by drought-deciduous vegetation, the canopy conductance component $(\mathrm{CaC})$ that is not associated with photosynthesis, the maximum transpiration rate $\left(E_{\max }\right)$, and the interception storage parameter of vegetation (Intc).

To be specific, the leaf longevity of each vegetation type is used to calculate its specific leaf area $\left(\mathrm{m}^{2} \mathrm{~g}^{-1}\right)$ based on Reich et al. (1998). The fraction of roots in two soil layers ( $f_{1}$ and $f_{2}$ are dimensionless, and $f_{1}+f_{2}=1$ ) affects relative soil mositure (wr, dimensionless) that is given by

$\mathrm{wr}=w_{1} \times f_{1}+w_{2} \times f_{2}$

where $w_{1}$ and $w_{2}$ are the fractions of available water (dimensionless, <1.0) in the upper and lower layer of soil, respectively. The minimum water scalar $\left(W_{\min }\right)$ adjusts daily drought leaf phenology because drought-deciduous plants shed their leaves when their water scalar falls below a specific threshold. The canopy conductance component, $\mathrm{CaC}$ $\left(\mathrm{mm} \mathrm{s}^{-1}\right)$, is a part of total, non-water-stressed canopy conductance, $\mathrm{gp}\left(\mathrm{mm} \mathrm{s}^{-1}\right)$, averaged over a grid cell as follows (Haxeltine and Prentice, 1996)

$\mathrm{gp}=\frac{1.6 \times D_{\mathrm{g}}}{D_{\mathrm{s}} \times \mathrm{ca} \times(1-\lambda)}+\mathrm{CaC}$

where $D_{\mathrm{g}}(\mathrm{mm})$ is daily water vapor expelled from plant leaves and derived from daytime net photosynthesis, ca is the mole fraction of atmospheric $\mathrm{CO}_{2}, \lambda$ is the optimal ratio of intercellular to ambient $\mathrm{CO}_{2}$ concentration, and $D_{\mathrm{s}}$ refers to the length of daylight in seconds.

The maximum daily transpiration rate, $E_{\max }(\mathrm{mm})$, is used to simulate the water supply function, $S(\mathrm{~mm})$, through the following expression:

$S=E_{\max } \times \mathrm{wr} \times \mathrm{ph}_{\mathrm{d}} \times \mathrm{fvc}$

where $\mathrm{ph}_{\mathrm{d}}$ is daily leaf phenology (dimensionless) of a vegetation type and fvc is the fraction of foliar vegetative cover in a grid cell. The vegetation-specific interception storage, Ints $(\mathrm{mm})$, is related to the interception storage parameter (Intc) (dimensionless) and is calculated as follows (Kergoat, 1998):

Ints $=\min \left(\operatorname{Pr}, \operatorname{Intc} \times \mathrm{LAI} \times \mathrm{ph}_{\mathrm{d}} \times \operatorname{Pr}\right)$

where LAI $\left(\mathrm{m}^{2} \mathrm{~m}^{-2}\right)$ is leaf area index and $\operatorname{Pr}(\mathrm{mm})$ is daily precipitation.

Parameters needed for simulating plant photosynthesis include the maximum foliar $\mathrm{N}$ content $N_{\max }\left(\mathrm{mg} \mathrm{g}^{-1}\right)$, the low $\left(T_{1}\right)$ and high $\left(T_{2}\right)$ temperature limits for $\mathrm{CO}_{2}$ uptake, and the lower $\left(T_{1}\right)$ and upper $\left(T_{\mathrm{h}}\right)$ ranges of optimum temperature for plant photosynthesis (Table 2). These parameters are used to 
Table 1. Hydrologic relevant parameters for predefined land covers.

\begin{tabular}{lrrrrrr}
\hline Predefined land cover types & $\begin{array}{r}\text { LeL } \\
\text { (years) }\end{array}$ & $f_{1}$ & $W_{\text {min }}$ & $\begin{array}{r}\mathrm{CaC}^{-1} \\
\left(\mathrm{~mm} \mathrm{~s}^{-1}\right)\end{array}$ & $\begin{array}{r}E_{\max } \\
\left(\mathrm{mm} \mathrm{day}^{-1}\right)\end{array}$ & Intc \\
\hline Evergreen needleleaf forest & 4.0 & 0.70 & 0.0 & 0.3 & 5.5 & 0.04 \\
Evergreen broadleaf forest & 2.5 & 0.80 & 0.0 & 0.5 & 5.5 & 0.02 \\
Deciduous needleleaf forest & 0.5 & 0.70 & 0.0 & 0.3 & 4.0 & 0.04 \\
Deciduous broadleaf forest & 0.5 & 0.70 & 0.0 & 0.5 & 4.0 & 0.02 \\
Mixed forest & 0.5 & 0.70 & 0.0 & 0.4 & 6.0 & 0.03 \\
Woodland & 0.5 & 0.80 & 0.0 & 0.3 & 4.0 & 0.02 \\
Shrub land & 0.5 & 0.83 & 0.1 & 0.4 & 5.5 & 0.02 \\
Grassland & 0.5 & 0.80 & 0.2 & 0.5 & 6.0 & 0.01 \\
Cropland & 0.5 & 0.80 & 0.2 & 0.5 & 4.5 & 0.01 \\
Bare & 0.5 & 0.75 & 0.0 & 0.0 & 1.0 & 0.00 \\
Urban & 0.5 & 0.75 & 0.0 & 0.0 & 0.0 & 0.00 \\
\hline
\end{tabular}

LeL is short for leaf longevity; $f_{1}$ stands for fraction of roots in soil upper layer. Fraction of roots in soil bottom layer $\left(f_{2}\right)$ equals one minus $f_{1} ; W_{\min }$ stands for minimum water scalar at which leaves shed by drought deciduous biome; CaC stands for canopy conductance component that is not associated with photosynthesis; $E_{\max }$ refers to maximum transpiration rate; Intc stands for interception storage parameter. The specific value of each parameter refers to published research (e.g. Sitch et al., 2003).

Table 2. Photosynthetic relevant parameters for predefined land covers.

\begin{tabular}{lrrrrrr}
\hline Predefined land cover types & $\begin{array}{r}N_{\max } \\
\left(\mathrm{mg} \mathrm{g}^{-1}\right)\end{array}$ & $\begin{array}{r}T_{1} \\
\left({ }^{\circ} \mathrm{C}\right)\end{array}$ & $\begin{array}{r}T_{1} \\
\left({ }^{\circ} \mathrm{C}\right)\end{array}$ & $\begin{array}{r}T_{2} \\
\left({ }^{\circ} \mathrm{C}\right)\end{array}$ & $\begin{array}{r}T_{\mathrm{h}} \\
\left({ }^{\circ} \mathrm{C}\right)\end{array}$ & $\begin{array}{r}\text { LAI } \\
\left(\mathrm{m}^{2} \mathrm{~m}^{-2}\right)\end{array}$ \\
\hline Evergreen needleleaf forest & 100.0 & -4.0 & 20.0 & 30.0 & 42.0 & 5.1 \\
Evergreen broadleaf forest & 100.0 & 2.0 & 25.0 & 30.0 & 55.0 & 5.4 \\
Deciduous needleleaf forest & 100.0 & -4.0 & 20.0 & 30.0 & 38.0 & 4.6 \\
Deciduous broadleaf forest & 120.0 & -4.0 & 20.0 & 30.0 & 38.0 & 4.5 \\
Mixed forest & 100.0 & -4.0 & 20.0 & 30.0 & 38.0 & 4.8 \\
Woodland & 100.0 & -4.0 & 20.0 & 30.0 & 38.0 & 3.0 \\
Shrub land & 100.0 & -4.0 & 15.0 & 30.0 & 45.0 & 2.1 \\
Grassland & 100.0 & -4.0 & 15.0 & 30.0 & 45.0 & 2.5 \\
Cropland & 100.0 & -4.0 & 15.0 & 30.0 & 45.0 & 4.2 \\
Bare & 0.0 & -4.0 & 10.0 & 30.0 & 45.0 & 1.3 \\
Urban & 0.0 & -4.0 & 10.0 & 30.0 & 45.0 & 0.3 \\
\hline
\end{tabular}

$N_{\max }$ is the maximum foliar $\mathrm{N}$ content; $T_{1}$ and $T_{\mathrm{h}}$ are the low and high temperature limits for $\mathrm{CO}_{2}$ uptake; $T_{1}$ and $T_{2}$ are the lower and upper ranges of optimum temperature for photosynthesis; LAI is short for leaf area index. The specific value of each parameter except for LAI refers to published work (e.g. Sitch et al., 2003). The LAI for each predefined land cover type refers to the Global Leaf Area Index Data from field measurements compiled at the Oak Ridge National Laboratory Distributed Active Archive Centre (DAAC)

(http://daac.ornl.gov/VEGETATION/lai_des.html).

calculate total daytime net photosynthesis of plants and convert daytime net photosynthesis into water vapor using an ideal gas equation (Haxeltine and Prentice, 1996), which is later used to simulate canopy conductance (see Eq. 2). The specific value of each parameter refers to published work (e.g. Smith et al., 2001; Sitch et al., 2003).

\subsection{Soil water balance in $\mathrm{LH}$}

The calculation of each hydrologic variable in $\mathrm{LH}$ is almost the same as that described in Gerten et al. (2004). We briefly introduce the calculation of major output variables (Fig. 1) for reference. Daily equilibrium PET rate $E_{\mathrm{eq}}(\mathrm{mm})$ is expressed as
$E_{\mathrm{eq}}=\frac{\Delta}{\Delta+\gamma} \times \frac{R_{n}}{L}$

where $R_{n}\left(\mathrm{~J} \mathrm{~m}^{-2} \mathrm{~d}^{-1}\right)$ refers to net radiation calculated from latitude, day of the year, sunshine hours, and air temperature; $\Delta$ is the rate of saturation vapor pressure increase with temperature; $\gamma\left(\mathrm{PaK}^{-1}\right)$ and $L\left(\mathrm{~J} \mathrm{Kg}^{-1}\right)$ are the psychrometric values of air and the latent heat of water vaporization adjusted by daily temperature, respectively. To avoid abrupt change in values of variables such as the ratio of ET to PET in high latitudes, LH assigns daily $E_{\text {eq }}$ a value of $10^{-6}$ when the calculated $E_{\text {eq }}$ is zero. Because equilibrium potential evapotranspiration $\left(E_{\mathrm{eq}}\right)$ rarely occurs in the real world, 
the Priestley-Taylor coefficient $(\alpha)$ with values that may vary from 1.26 (for well-watered land) to 1.4 (for dry land) is used to estimate potential evapotranspiration $\left(E_{\mathrm{p}}\right)$ at different locations as follows:

$E_{\mathrm{p}}=E_{\mathrm{eq}} \times \alpha$.

Actual ET is the sum of interception loss, vegetation transpiration, and evaporation from soil. Daily interception loss, $L(\mathrm{~mm})$, is a product of daily PET $\left(E_{\mathrm{p}}\right)$ and the fraction of day-time, $\omega$ (dimensionless), when the canopy is wet is as follows:

$L=E_{\mathrm{p}} \times \omega$.

The value of $\omega$ is related to the canopy interception storage capacity. Vegetation transpiration is estimated based on the comparison between an atmosphere-controlled demand function and a plant-controlled supply function (see Eq. 3).

Daily evaporation $E_{\mathrm{d}}(\mathrm{mm})$ from soil follows Huang et al. (1996) as

$E_{\mathrm{d}}=E_{\mathrm{p}} \mathrm{wr}_{20}(1-\mathrm{fvc})$

where $\mathrm{wr}_{20}$ (dimensionless) represents the relative moisture in the evaporation layer $(20 \mathrm{~cm})$ of the soil column; fvc is again the fraction of foliar vegetative cover in a cell, as in Eq. (3).

Daily soil water content in both layers at day $i$ is updated taking account of the water content from the previous day, snowmelt $M_{i}(\mathrm{~mm})$, throughfall $\operatorname{Pr}_{\mathrm{t}}(\mathrm{mm})$, transpiration $E_{\mathrm{T}, i}$ $(\mathrm{mm})$, evaporation $E_{\mathrm{d}, i}(\mathrm{~mm})$, percolation $p_{1, i}(\mathrm{~mm})$ through two layers, and runoff $R_{1, i}(\mathrm{~mm})$ during the current day $i$ :

$\left\{\begin{array}{l}\Delta \mathrm{SW}_{1, i}=\Delta \mathrm{SW}_{1, i-1}+\mathrm{Pr}_{\mathrm{t}, i}+M_{i}-\beta_{1, \mathrm{i}} \times E_{\mathrm{T}, i}-E_{\mathrm{d}, i}-p_{1, i}-R_{1, i} \\ \Delta \mathrm{SW}_{2, i}=\Delta \mathrm{SW}_{2, i-1}+p_{1, \mathrm{i}}-\beta_{2, \mathrm{i}} \times E_{\mathrm{T}, i}-R_{2, \mathrm{i}}-p_{2, \mathrm{i}}\end{array}\right.$

where $\Delta \mathrm{SW}_{1, \mathrm{i}}$ and $\Delta \mathrm{SW}_{2, \mathrm{i}}(\mathrm{mm})$ are daily changes in soil water content of both layers at day $i ; \beta_{1}$ and $\beta_{2}$ represent the fractions of water extracted for transpiration from each layer $\left(\beta_{1}+\beta_{2}=1\right)$. The surface runoff $\left(R_{1, i}\right)$ and subsurface runoff $\left(R_{2, i}\right)$ are estimated from the excess of water over field capacity of the two soil layers, respectively. The total runoff in a grid cell is the sum of surface and subsurface runoff.

\subsection{Snowmelt computation in $\mathrm{LH}$}

Unlike LPJ-DGVM (Sitch et al., 2003; Gerten et al., 2004) which uses a degree-day method for snowmelt calculation, LH combines both the effects of solar radiation and temperature on snowmelt (mm) at day $i$ as follows (e.g. Kane et al., 1997):

$M_{i}=\left\{\begin{array}{l}c 1 \times(1-\mathrm{Sal}) \times \mathrm{dr}_{i} \times \mathrm{dl}_{i} \quad \text { if } T_{\text {air }}<T_{\text {snow }} \\ c 1 \times(1-\mathrm{Sal}) \times \mathrm{dr}_{i} \times \mathrm{dl}_{i}+c 2 \times\left(T_{\text {air }}-T_{\text {snow }}\right) \times \operatorname{Pr}\end{array}\right.$

$$
\text { if } T_{\text {air }}>=T_{\text {snow }}
$$

where Sal is snow albedo; $\mathrm{dr}_{i}\left(\mathrm{~W} \mathrm{~m}^{-2} \mathrm{~h}^{-1}\right)$ is downward net shortwave radiation flux in day $i ; \mathrm{dl}_{i}(\mathrm{~h})$ is day length in day $i$; $T_{\text {air }}\left({ }^{\circ} \mathrm{C}\right)$ is daily air temperature; $T_{\text {snow }}\left({ }^{\circ} \mathrm{C}\right)$ is temperature $\left(0^{\circ} \mathrm{C}\right)$ at which snow occurs; $\operatorname{Pr}(\mathrm{mm})$ is daily precipitation; and $c 1$ and $c 2$ are empirical coefficients. The value of $c 1$ ranges from 0.0002 for grass, crop, and not well-forested land to 0.001 for well-forested land. $c 2$ is set at 0.065 level in $\mathrm{LH}$.

\section{Data}

\subsection{Land cover and soil properties}

The global land cover classification from the Global Land Cover Facility (GLCF) at the University of Maryland (http: //glcf.umiacs.umd.edu/data/vcf/) is used to define input land cover at each grid cell that is most likely to exist in the conterminous US or worldwide. After excluding water, we grouped the rest of 13 GLCF land cover classes into 11 types (Tables 1 and 2). These 11 land cover types were regridded onto both the Parameter-elevation Regressions on Independent Slopes Model (PRISM) 2.5-arc-min elevation points (Daly et al., 2000, 2002) and CRU TS 0.5-degree climate points (Mitchell and Jones, 2005), respectively. Following the same approach, the GLCF Vegetation Continuous Fields (VCF) data (Hansen et al., 2000, 2003) were used to define fraction of foliar vegetative cover of a GLCF-based land cover in a grid cell. The VCF data contained proportional estimates for three cover types: woody vegetation, herbaceous vegetation, and bare ground. The total percentage cover for three cover types in a cell is 100 percent (Hansen et al., 2000).

Our soil data for the conterminous US were derived from the Miller and White (1998) soil texture classes that were gridded at a $250 \mathrm{~m}$ spatial resolution. These soil texture classes were based on the State Soil Geographic (STATSGO) Database, distributed by the United States Department of Agriculture Natural Resources Conservation Service. We reclassified 16 standard soil classes in STATSGO data into eight classes to match those defined in both LH and LPJDGVM. The soil data were regridded onto 2.5 arc-min PRISM elevation points. For the global application of LH, we used soil texture data distributed with LPJ-DGVM at a 0.5 -degree grid. Annual atmospheric $\mathrm{CO}_{2}$ concentrations for both the US and globally were from Schlesinger and Malyshev (2001).

\subsection{Climate data}

To apply LH in the US, we used monthly mean temperature $\left({ }^{\circ} \mathrm{C}\right)$ and precipitation $(\mathrm{mm})$ at 2.5 arc-min grid cells developed by the PRISM Climate Group (Daly et al., 2000, 2002). Monthly percent sunshine (\%) and wet-day frequency (days) were derived from the CRU TS 3.0 data sets (Mitchell and Jones, 2005). We interpolated 0.5-degree CRU wetday frequency data onto the PRISM 2.5-arc-min elevation 
points following the approach described in Tang and Beckage (2010), in which we first treated climatic value at each CRU grid cell as a function of its latitude, longitude and elevation to estimate the local lapse rate of wet-day frequency. The calculated local lapse rate was then used to interpolate CRU data to PRISM 2.5 arc-min resolution considering elevational differences between CRU and PRISM points. These adjusted climatic values for CRU points were bilinearly interpolated onto PRISM points. The CRU sunshine data were downscaled by bilinear interpolation. To apply LH globally, we directly used CRU TS 3.0 monthly mean temperature $\left({ }^{\circ} \mathrm{C}\right)$, precipitation $(\mathrm{mm})$, percent cloud cover $(\%)$, and wet day frequency (days) data on its 0.5 -degree grid.

\subsection{Reference data and evaluation approaches}

Several existing sets of observed or simulated data generated using different methods at different spatial scales were used to test LH's performance in simulating ET, soil moisture, and surface runoff for the conterminous US (Table 3). The German ET data for the Florida Everglades (US) (German, 2000) was evaluated on the basis of the Bowen-ratio energy budget method (Bowen, 1926). All data needed for application of the Bowen-ratio method, including net radiation, soil temperature, water level, air temperature, and vapor pressure, were measured at 15 -min intervals spanning the year from 1996 to 2001 and at nine sites ranging from $24.75^{\circ} \mathrm{N}$ to $26.25^{\circ} \mathrm{N}$ and from $79.75^{\circ} \mathrm{W}$ to $81.25^{\circ} \mathrm{W}$ (German, 2000). The Vörösmarty et al. ET data (hereafter Vörösmarty ET, Vörösmarty et al., 1998) were computed by a global-scale water balance model that considered effects of wind speed and vapor pressure on surface hydrology.

Illinois soil-moisture data consisting of total soil moisture were measured at 19 stations in Illinois in the US. These data span an interval from January 1981 to June 2004 and were calibrated with gravimetric observations. We did not use the first three years (1981, 1982 and 1983) for comparison because the data have smaller variability than the rest of the record (Hollinger and Isard, 1994). Iowa soil-moisture data consisted of observations from two catchments located at $41.2^{\circ} \mathrm{N}$ and $95.6^{\circ} \mathrm{W}$. Each catchment had three sites where soil-moisture observations were made. These observations gave $23 \mathrm{yr}$ of record spanning from 1972 to 1994, but observations were made mostly between April and October (Entin, 1998; Entin et al., 2000). Both Illinois and Iowa soil moisture data are available from the Global Soil Moisture Data Bank (Robock et al., 2000). When necessary, we converted measured soil moisture into millimeters to match LH-simulated moisture levels. We only used soil moisture from the top $50 \mathrm{~cm}$ of soil layers because other information, such as soil density for the rest of layers, was not available for unit conversion.

The Global Runoff Data Centre (GRDC) composite runoff fields (CRF) (Fekete et al., 2002) were used to evaluate the spatial pattern of LH-simulated annual runoff for the conter- minous US. The GRDC CRF was developed by combining observed river discharge information with climate-driven water balance model outputs. The observed discharge was derived from selected gauging stations from the World Meteorology Organization GRDC data archive. These station data were coregistered to a simulated topological network at a 0.5 degree land grid.

US Geological Survey (USGS) water data from 13 river gage stations (Table 4) were used to test LH-simulated river stream flow for the years 1981-2006. We selected only 13 rivers for comparison because (i) the derived watersheds from 13 gage stations cover most of the conterminous US (Supplement Fig. S1) and (ii) the observed discharge information might not always be available for other rivers during the study period. We converted simulated surface runoff $(\mathrm{mm})$ into cubic meters per second $\left(\mathrm{m}^{3} \mathrm{~s}^{-1}\right)$ under the assumption that modeled surface runoff at all grid cells inside a watershed flows out of its gage station within the given month. The conversion of modeled surface runoff into stream flow $\left(f_{\mathrm{LH}, j}\right)$ in month $j$ is expressed as

$f_{\mathrm{LH}, j}=\frac{1}{n} \sum_{i=1}^{n} \operatorname{srf}_{i, j} \times \mathrm{DA} /\left(\mathrm{DS}_{j} \times 86400\right) / 1000$

where $\operatorname{srf}_{i, \mathrm{j}}$ is LH-simulated surface runoff $(\mathrm{mm})$ at grid cell $i$ in month $j ; n$ is the number of grid cells inside a watershed; DA is the drainage area $\left(\mathrm{m}^{2}\right)$ for a gage station; and $\mathrm{DS}_{j}$ is the number of days in month $j$. We also converted the USGS stream flow data from cubic feet per second into cubic meters per second for comparison.

We used observed river discharges for 10 large rivers worldwide (Tables 3 and 4) to further evaluate LH's reliability, largely because the hydrological component from LPJDGVM was originally developed for global-scale vegetation and hydrology simulation. We used Cogley (1998) runoff data on a 1-degree grid to evaluate the spatial pattern of LHsimulated annual runoff for the world (Table 3 ). The global 0.5-degree annual runoff data based on field observations from Fekete et al. (1999) were used to evaluate LH-simulated magnitudes of annual runoff globally and in different latitudinal zones (Table 3 ).

We used statistical measures such as R-squared $\left(R^{2}\right)$, rootmean-squared-error (RMSE), and the Nash-Sutcliffe coefficient (Nr) (Nash and Sutcliffe, 1970) to quantify the agreement between modeled and simulated/observed ET, soil moisture, and surface runoff. For example, the Nash-Sutcliffe coefficient was used to quantify the agreement between modeled and observed stream flow for selected rivers in the conterminous US.

\subsection{Experimental simulations}

Two experimental simulations using LH were performed in this study. The first was run using a degree-day method for snowmelt computation and the second was run under high 
Table 3. List of observed and simulated data to test LH's performance.

\begin{tabular}{|c|c|c|c|c|}
\hline Testing data list & Methods & $\begin{array}{l}\text { Temporal resolu- } \\
\text { tion }\end{array}$ & Size & Data sources* \\
\hline (1) German ET & Composite & Monthly for & Plots & German (2000) \\
\hline (2) Vörösmarty ET & Simulated & $\begin{array}{l}\text { 1996-2000 } \\
\text { Monthly }\end{array}$ & $0.5^{\circ}$ & Vörösmarty et al. (1998) \\
\hline $\begin{array}{l}\text { (3) Illinois soil } \\
\text { moisture }\end{array}$ & Observed & $\begin{array}{l}\text { Monthly for } \\
\text { 1981-2004 }\end{array}$ & Plots & Hollinger and Isard (1994) \\
\hline (4) Iowa soil moisture & Observed & $\begin{array}{l}\text { Monthly for } \\
\text { 1981-1994 }\end{array}$ & plots & $\begin{array}{l}\text { Entin (1998), Entin et al. } \\
(2000)\end{array}$ \\
\hline (5) The GRDC CRF & Composite & Annual & $0.5^{\circ}$ & Fekete et al. (2002) \\
\hline $\begin{array}{l}\text { (6) The USGS water } \\
\text { data }\end{array}$ & Observed & $\begin{array}{l}\text { Monthly for } \\
\text { 1981-2006 }\end{array}$ & Plots & http://waterdata.usgs.gov/ \\
\hline (7) Cogley runoff data & Derived & Annual & $1^{\circ}$ & Cogley (1998) \\
\hline $\begin{array}{l}\text { (8) The Global River } \\
\text { Discharge Database }\end{array}$ & Observed & $\begin{array}{l}\text { Annual for } \\
1961-1990\end{array}$ & Plots & $\begin{array}{l}\text { http://www.sage.wisc.edu/ } \\
\text { riverdata/ }\end{array}$ \\
\hline $\begin{array}{l}\text { (9) Gridded Global } \\
\text { Runoff }\end{array}$ & Observed & Annual & $0.5^{\circ}$ & Fekete et al. (1999) \\
\hline
\end{tabular}

* Soil moisture data are available from http://climate.envsci.rutgers.edu/soil_moisture/ owned by Robock et al. (2000). The global runoff data are available from http://www.grdc.sr.unh.edu/html/Data/index.html.

Table 4. Details of river gage stations used for model evaluation in both the US and globally.

\begin{tabular}{|c|c|c|c|c|c|}
\hline \multirow{2}{*}{$\begin{array}{l}\text { LH's } \\
\text { evaluation }\end{array}$} & \multirow[t]{2}{*}{ River names and states/country } & \multirow{2}{*}{$\begin{array}{r}\text { Gage number/ } \\
\text { name }\end{array}$} & \multicolumn{2}{|c|}{ Location } & \multirow{2}{*}{$\begin{array}{r}\text { Drainage } \\
\text { area }\left(\mathrm{km}^{2}\right)\end{array}$} \\
\hline & & & Long. $\left({ }^{\circ}\right)$ & Lat. $\left(^{\circ}\right)$ & \\
\hline \multirow{13}{*}{$\mathrm{US}^{\mathrm{a}}$} & 1. Sacramento in Colusa, CA & 11389500 & -122.00 & 39.21 & 31313 \\
\hline & 2. Willamette in Portland, OR & 14211720 & -122.67 & 45.52 & 29008 \\
\hline & 3. Snake near Anatone, WA & 13334300 & -116.98 & 46.10 & 240756 \\
\hline & 4. Missouri in Hermann, MO & 06934500 & -91.44 & 38.71 & 1353269 \\
\hline & 5. Mississippi in Chester, IL & 07020500 & -89.84 & 37.90 & 1835266 \\
\hline & 6. Ohio in Metropolis, IL & 03611500 & -88.79 & 37.15 & 525768 \\
\hline & 7. Connecticut in Thompsonville,CT & 01184000 & -72.61 & 41.99 & 25019 \\
\hline & 8. Susquehanna in Marietta, PA & 01576000 & -76.53 & 40.05 & 67314 \\
\hline & 9. Coolrado in Columbus, TX & 08161000 & -96.54 & 29.71 & 107847 \\
\hline & 10. Wateree near Camden, SC & 02148000 & -80.65 & 34.24 & 13131 \\
\hline & 11. Alabama in Claiborne, $\mathrm{AL}^{\mathrm{c}}$ & 02428400 & -87.55 & 31.62 & 55615 \\
\hline & 12. Apalachicola near Sumatra, $\mathrm{FL}^{\mathrm{c}}$ & 02319570 & -85.02 & 28.95 & 19200 \\
\hline & 13. Arkansas near Haskell, OK & 07165570 & -95.64 & 35.82 & 75473 \\
\hline \multirow{10}{*}{ Globallyb } & 1. Danube in Romania & Ceatal Izmail & 28.8 & 45.18 & 807000 \\
\hline & 2. Congo in Congo & Kinshasa & 15.3 & -4.3 & 3475000 \\
\hline & 3. Murray in Australia & Lock9 Upper & 141.6 & -34.19 & 775196 \\
\hline & 4. Yenisei in Russia & Igarka & 86.50 & 67.48 & 2440000 \\
\hline & 5. Mississippi in USA & Arkansas City & -91.24 & 33.56 & 2903428 \\
\hline & 6. Chang jiang in China & Datong & 117.61 & 30.76 & 1705383 \\
\hline & 7. Xi jiang in China & Wuzhou3 & 111.3 & 23.48 & 329705 \\
\hline & 8. Mackenzie in Canada & Norman Wells & -126.86 & 65.28 & 1570000 \\
\hline & 9. Amazon in Brazil & Obidos & -55.55 & -1.91 & 4618746 \\
\hline & 10. Blue Nile in Sudan & Khartoum & 32.55 & 15.61 & 325000 \\
\hline
\end{tabular}

a The river gage stations are based on USGS National Water Information System (http://waterdata.usgs.gov/nwis/); ${ }^{b}$ the river gage stations worldwide are based on the Global River Discharge Database (http://www.sage.wisc.edu/riverdata/). ${ }^{\mathrm{c}}$ The Alabama and Apalachicola River watersheds are combined together for reference as the Alabama River watershed. 
atmospheric $\mathrm{CO}_{2}$ concentration (650 ppm). Results from the first simulation were compared to the simulation under the consideration of both temperature and solar radiation effects on snowmelt and actual atmospheric $\mathrm{CO}_{2}$ concentration. Results from the second simulation were compared to the simulation run under low atmospheric $\mathrm{CO}_{2}$ concentration (360 ppm). Such comparisons aimed to evaluate how the addition of solar radiation effect on snowmelt impacts modeled river stream flow and how increasing atmospheric $\mathrm{CO}_{2}$ concentration affects modeled actual evapotranspiration.

\section{Results}

\subsection{LH-simulated actual ET and its evaluation in the US}

LH-simulated annual actual ET averaged $536 \mathrm{~mm}$ in the US and varied from 0 to $1305 \mathrm{~mm}$ among grid cells (Fig. 2a). The lowest ET was simulated in southeastern California where annual precipitation is low $(<160 \mathrm{~mm})$ and temperature is high $\left(>21^{\circ} \mathrm{C}\right.$ ) (Supplement Fig. S2). The highest ET was simulated in coastal areas of the southern and southeastern US where both annual precipitation $(>1400 \mathrm{~mm}$ ) and temperature $\left(>20^{\circ} \mathrm{C}\right)$ are high. In the eastern US, annual ET was simulated to decrease from south to north (Fig. 2a), a result of energy- and temperature-related latitudinal gradients (Supplement Fig. S2). In the western US, annual ET was less than $600 \mathrm{~mm}$ in most areas and did not vary much latitudinally. In some mountain ranges of the western US, such as the (Pacific) Coast Range, simulated annual ET ranged from 600 to $900 \mathrm{~mm}$ (Fig. 2a), attributed to high annual precipitation $(>2600 \mathrm{~mm}$ ) in these areas (Supplement Fig. S2).

The magnitudes of LH-simulated annual ET among grid cells agreed well with those from Vörösmarty ET data (Vörösmarty et al., 1998). For example, the simulated mean annual ET (533 mm) was close to $572 \mathrm{~mm}$ from Vörösmarty ET. The range (0 to $1305 \mathrm{~mm}$ ) of LH-simulated annual ET was similar to the range of 53 to $1414 \mathrm{~mm}$ of Vörösmarty ET data. The standard deviation of LH-simulated annual ET was $238 \mathrm{~mm}$, close to the $269 \mathrm{~mm}$ from Vörösmarty ET data. The spatial pattern of LH-simulated ET (Fig. 2a) agrees well visually with that depicted by the Vörösmarty ET data (Fig. 2b). In the eastern US, for instance, annual ET decreased from more than $1200 \mathrm{~mm}$ in the south to below $600 \mathrm{~mm}$ in the north in both the simulated and Vörösmarty ET data. In the western US, annual ET varied from 0 to $600 \mathrm{~mm}$ in most areas except for mountain ranges (Fig. 2).

When averaged for all grid cells in a watershed, LHsimulated monthly ET was strongly correlated $\left(R^{2}>0.72\right.$, $p<0.01)$ with values from Vörösmarty ET data in 12 large watersheds (Fig. 3 and Table 5), indicating that LH captured well the variation in monthly ET illustrated in the Vörösmarty ET data. Average monthly ET (based on a 12month mean) under the LH simulation was close (difference $<10 \%)$ to those from Vörösmarty ET data respectively in
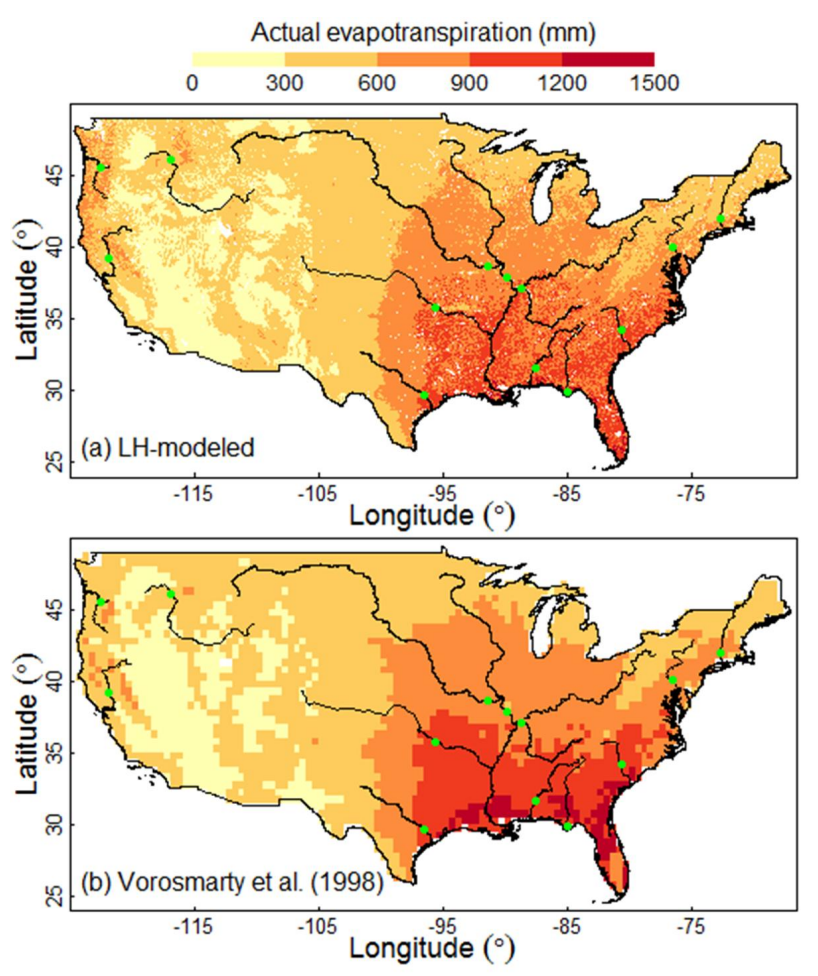

Fig. 2. (a) The LH-simulated 26-yr (1981-2006) average annual actual ET at 2.5 arc-min grid cells; (b) annual actual ET from Vörösmarty et al. (1998) at 0.5-degree grid cells. The white areas in (a) and (b) are water excluded for simulation.

the Sacramento, Snake, Missouri, Mississippi, Ohio, Connecticut, Susquehanna, Colorado, and Arkansas watersheds (Table 5). Major differences occurred in estimates of monthly ET for the Willamette, Alabama, and Wateree watersheds, in which LH-simulated monthly ET was $19 \%$ higher, $16 \%$ lower, and $20 \%$ lower than Vörösmarty monthly ET, respectively (Table 5). In more detail, LH-simulated ET in late spring and early summer in most watersheds was smaller than those from Vörösmarty ET data (Fig. 3).

When compared to local ET data from the Florida everglades, LH-simulated monthly ET over the years 19962001 corresponded well $\left(R^{2}=0.61, p<0.01\right)$ to the measured data (German, 2000) (Fig. 4). LH-simulated monthly ET averaged $91 \mathrm{~mm}$, approximating the $94 \mathrm{~mm}$ of German ET. The standard deviation of LH-simulated monthly ET was $24 \mathrm{~mm}$, close to $25 \mathrm{~mm}$ in German ET data. In addition, LH-simulated monthly ET ranged from 47 to $144 \mathrm{~mm}$, within the range of German ET which varied from $29 \mathrm{~mm}$ to $153 \mathrm{~mm}$. The RMSE between LH-simulated and German monthly ET was 18.5 , less than $21 \%$ of average monthly ET for compared data. Nevertheless, LH under- and overestimated monthly ET in some specific months such as April of 1998 (Fig. 4). 
Table 5. Comparison between LH-simulated and Vörösmarty et al. ET (Vörösmarty et al., 1998) data in12 major river watersheds in the US.

\begin{tabular}{lrrr|rrr|rr}
\hline & \multicolumn{2}{c}{ Vörösmarty et al. ET $(\mathrm{mm})$} & \multicolumn{2}{c}{ LH-simulated ET (mm) } & \multicolumn{2}{c}{ Statistics } \\
\cline { 2 - 8 } Rivers & $\min$ & $\max$ & mean & $\min$ & $\max$ & mean & $R^{2}$ & $\Delta(\%)$ \\
\hline 1. Sacramento & 6 & 90 & 37 & 12 & 64 & 38 & 0.72 & 0.6 \\
2. Willamette & 7 & 83 & 43 & 7 & 100 & 51 & 0.94 & 19.3 \\
3. Snake & 1 & 91 & 27 & 6 & 53 & 29 & 0.76 & 7.5 \\
4. Missouri & 0 & 118 & 41 & 6 & 69 & 37 & 0.88 & -10.0 \\
5. Mississippi* & 0 & 132 & 55 & 6 & 108 & 51 & 0.88 & -5.8 \\
6. Ohio & 0 & 125 & 61 & 8 & 116 & 58 & 0.88 & -4.6 \\
7. Connecticut & 0 & 111 & 43 & 2 & 120 & 40 & 0.81 & -6.3 \\
8. Susquehanna & 0 & 110 & 46 & 4 & 124 & 46 & 0.86 & -0.6 \\
9. Colorado & 12 & 73 & 48 & 28 & 70 & 48 & 0.79 & -0.4 \\
10. Wateree & 0 & 135 & 78 & 15 & 110 & 66 & 0.85 & -15.8 \\
11. Alabama & 30 & 138 & 90 & 22 & 113 & 72 & 0.90 & -20.1 \\
12. Arkansas & 0 & 104 & 47 & 13 & 71 & 44 & 0.86 & -6.8 \\
\hline
\end{tabular}

* The observed monthly stream flow subtracted that from the Missouri River in model comparison.
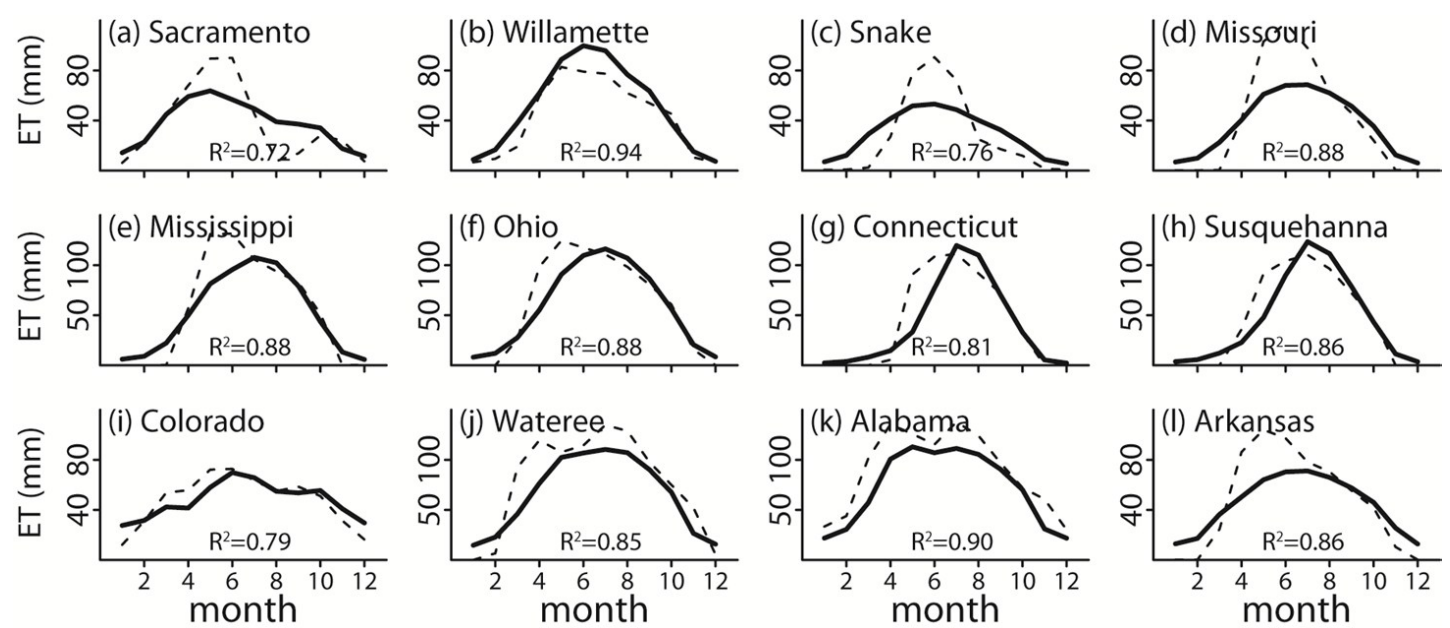

Fig. 3. Comparison between LH-simulated (solid line) and Vörösmarty et al. monthly ET (Vörösmarty et al., 1998) (dashed line) in the 12 river watersheds.

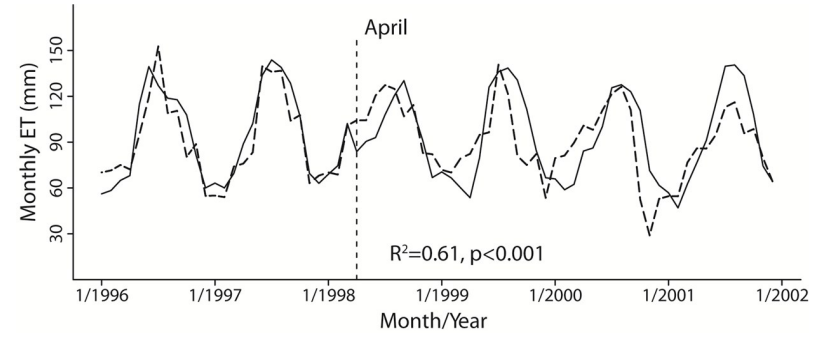

Fig. 4. Comparison between LH-simulated (black line) to observed (dashed line) monthly ET (German, 2000) during the years 19962001 in Florida Everglades (US).

\subsection{LH-simulated soil moisture and its evaluation in the US}

LH-simulated annual soil moisture averaged $107 \mathrm{~mm}$ over the US and ranged from 0 to $325 \mathrm{~mm}$ among grid cells (Fig. 5). Annual soil moisture was simulated to be highest in mountain areas, such as the Pacific Coast Ranges, the Cascade Range of Oregon, and the Appalachian Mountains in the eastern and northeastern US (Fig. 5). In these areas, LH-simulated annual soil moisture exceeded $160 \mathrm{~mm}$, attributable to low regional annual temperature $\left(<9^{\circ} \mathrm{C}\right)$ and high precipitation $(>1500 \mathrm{~mm})$. Annual soil moisture was simulated to be low $(<100 \mathrm{~mm})$ in most of the western US. In these regions, annual precipitation was relatively low $(<400 \mathrm{~mm})$ while annual mean temperature can be more than $9{ }^{\circ} \mathrm{C}$ (Supplement Fig. S2). 


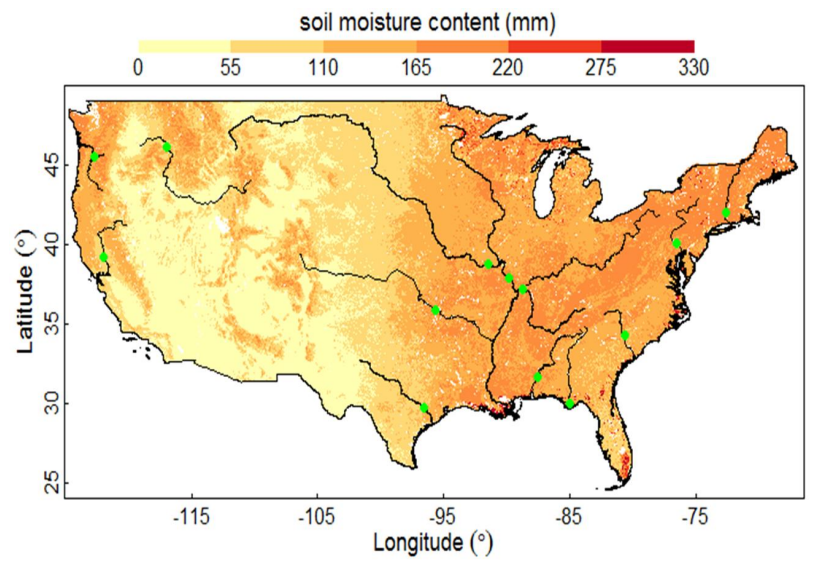

Fig. 5. LH-simulated 26-yr (1981-2006) mean annual soil moisture in the top $50 \mathrm{~cm}$ of soil layers.

When LH-simulated monthly soil moisture was compared to Illinois soil moisture (Table 3$)$, the statistics $\left(R^{2}=0.79\right.$, $p<0.01)$ suggest that LH captured well the variation in monthly soil moisture in this region during the years 1984 2001 (Fig. 6a). The LH-simulated monthly soil moisture averaged $160 \mathrm{~mm}$, equaling $160 \mathrm{~mm}$ from observed data. LHsimulated monthly mean value ranged from 87 to $202 \mathrm{~mm}$ during the period 1984-2001, resembling observed values ranging from 86 to $201 \mathrm{~mm}$. The standard deviation of LHsimulated soil moisture was $29.3 \mathrm{~mm}$, close to $28.9 \mathrm{~mm}$ from the observations. The RMSE between LH-simulated and observed values for 246 months was 14, indicating that $\mathrm{LH}$ simulated well monthly soil moisture in this region though it under- and overestimated soil moisture in some months (Fig. 6a).

Additional comparison against observed soil moisture in two Iowa catchments (Table 3) still suggested that LH can capture the variation of monthly soil moisture at local scales as indicated by the coefficient $\left(R^{2}=0.40, p<0.01\right)$ between the two data sets (Fig. 6b). For the whole period 1981-2004, LH-simulated monthly soil moisture averaged $149 \mathrm{~mm}$, only $10 \mathrm{~mm}$ lower than the average from observed data $(159 \mathrm{~mm})$. LH-simulated monthly soil moisture ranged from 76 to $208 \mathrm{~mm}$, a slightly broader range than observed values (93 to $201 \mathrm{~mm}$ ). Nevertheless, LH-simulated soil moisture in this particular region was comparatively more variable than observed values, as indicated by the standard deviations of $26 \mathrm{~mm}$ for $\mathrm{LH}$ and $34 \mathrm{~mm}$ for observation. The RMSE between LH-simulated and observed values for 91 points was 29 , accounting for $18 \%$ of observed mean monthly soil moisture.

\subsection{LH-simulated surface runoff and its evaluation in the US}

LH-simulated annual surface runoff averaged $234 \mathrm{~mm}$ in the US and ranged between 0 and $6440 \mathrm{~mm}$ among grid cells,
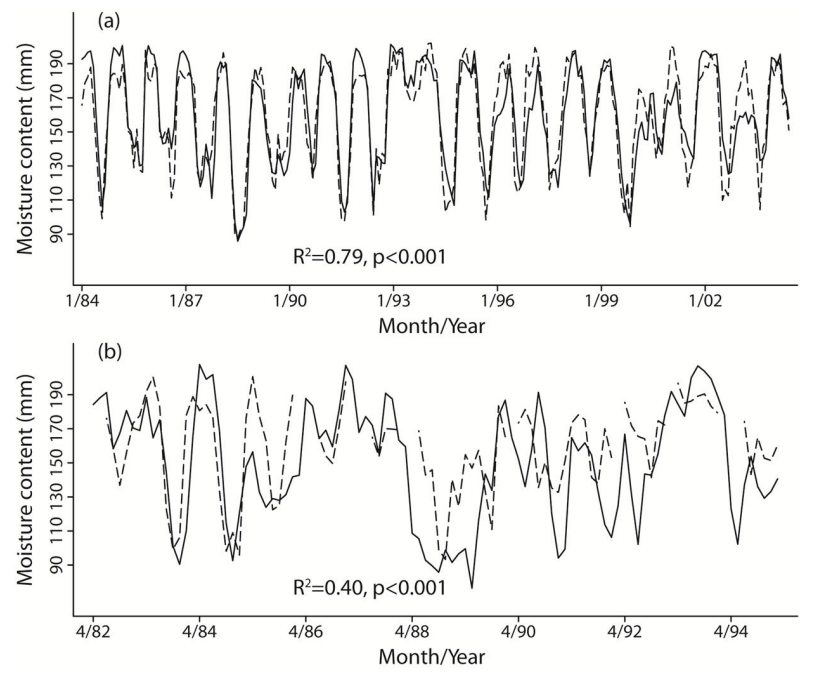

Fig. 6. Comparison between LH-simulated (black line) and observed (dashed line) soil moisture in the top $50 \mathrm{~cm}$ of soil layers in (a) Illinois in the US during the years 1984-2004 (Hollinger and Isard, 1994), and (b) Iowa in the US during the years 1981-1994 (Entin, 1998; Entin et al., 2000). For Illinois soil moisture, only half year (till June) data for 2004 are available. LH-simulated soil moisture in Illinois was averaged for all grid cells ranging from $91.25^{\circ} \mathrm{W}$ to $88.25^{\circ} \mathrm{W}$ and from $37.25^{\circ} \mathrm{N}$ to $42.25^{\circ} \mathrm{N}$; a spatial extent that approximately matches the extent of Illinois soil moisture. Measured soil moisture in Iowa was not available for some months and years, but most records were available between April and October.

with a standard deviation of $307 \mathrm{~mm}$ (Fig. 7a). As was the case for annual soil moisture, surface runoff was simulated to be highest in mountain areas. In these regions, annual precipitation was comparatively high while annual mean temperature was comparatively low (Supplement Fig. S2). Annual surface runoff was modeled to be low in most of the western US, attributed to low annual precipitation $(<400 \mathrm{~mm})$. Overall, LH-simulated surface runoff was more than $200 \mathrm{~mm}$ in the eastern US but less than $200 \mathrm{~mm}$ in the western US (Fig. 7a).

The magnitudes of LH-simulated surface runoff agreed well with the GRDC CRF data (Fig. 7b). Annual surface runoff averaged $215 \mathrm{~mm}$ in the GRDC CRF data, which was only $19 \mathrm{~mm}$ lower than LH-simulated annual surface runoff $(234 \mathrm{~mm})$ for the US. The spatial pattern of LH-simulated annual surface runoff was consistent with that pictured by the GRDC CRF data (Fig. 7a and b). For example, both data showed that annual surface runoff is above $200 \mathrm{~mm}$ in the eastern US but below $200 \mathrm{~mm}$ in the western US. In addition, annual surface runoff in both compared data sets was relatively high in mountain areas, such as the Pacific Coast Ranges and Appalachian Mountains in the eastern US. Overall, LH-simulated annual surface runoff was more variable relative to the GRDC CRF data as illustrated by the standard 


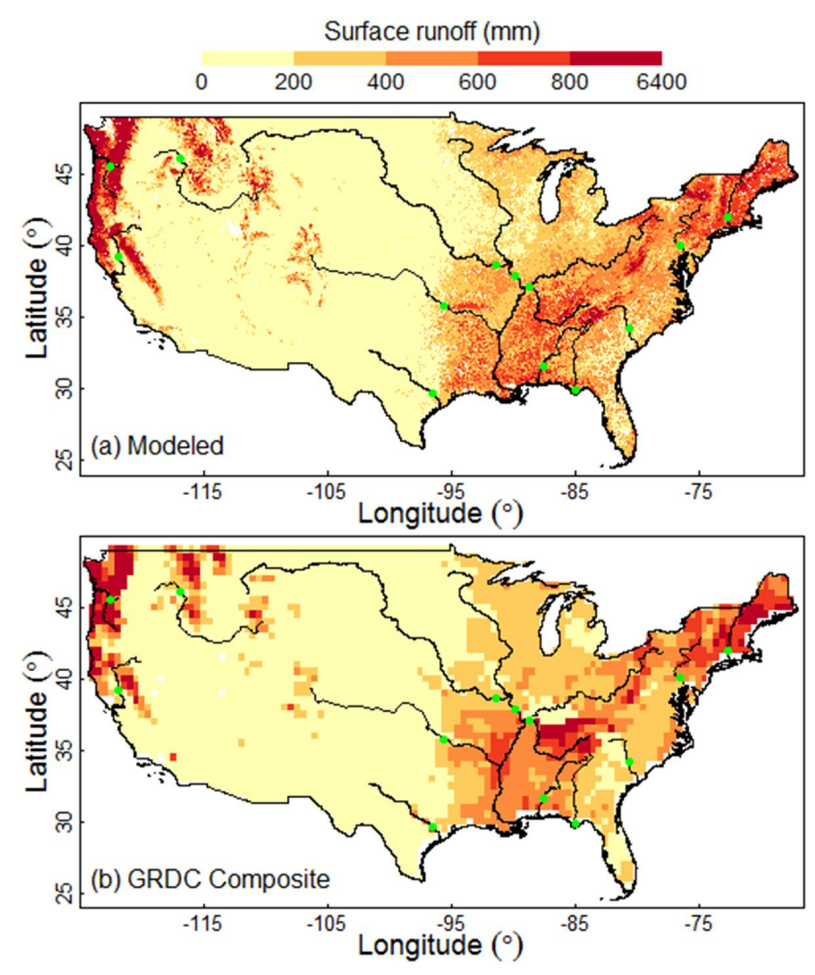

Fig. 7. (a) The LH-simulated annual surface runoff at 2.5 arc-min grid cells and (b) the GRDC composite annual runoff at 0.5-degree grid cells (Fekete et al., 2002) for the conterminous US.

deviations of LH-simulated surface runoff $(307 \mathrm{~mm})$ and the GRDC CRF data (278 mm).

Further comparison of LH-simulated monthly stream flow to the USGS water data demonstrated that LH was able to correctly simulate the variations in monthly stream flow in most major rivers in the US $\left(R^{2}>0.50, p<0.01\right.$; $\mathrm{Nr}>0.51$, Moriasi et al., 2007) (Fig. 8). Especially for watersheds where forest is the dominant land cover (Supplement Fig. S3), the LH-simulated monthly stream flow agreed well $\left(R^{2}>0.65, p<0.01 ; \mathrm{Nr}>0.52\right)$ with observed values for the years 1981-2006. These rivers include the Willamette, Ohio, Susquehanna, Connecticut, and Wateree (Fig. 8 and Table 6). In contrast, for watersheds where grass, shrubs and/or crops are dominant land covers, the agreement between compared data was weaker $\left(R^{2}<0.65\right)$. These rivers include the Snake, Missouri, Mississippi, and Colorado, but not the Arkansas River for which the modeled monthly stream flow agreed well with the observed stream flow (Fig. 8 and Table 6).

The magnitudes of LH-simulated mean monthly stream flow for the years 1981-2006 were close (difference $<11 \%$ ) to measured mean monthly stream flow for most of the 12 rivers, including the Willamette, Snake, Missouri, Mississippi, Ohio, Connecticut, Susquehanna, Wateree, and Alabama (Table 6). Major difference occurred in estimates of monthly mean stream flow for the Sacramento and Colorado River. For these two rivers, LH-simulated average monthly stream flow was $24.0 \%$ higher and $19.6 \%$ lower than their counterparts from measured data, averaging 347 and $80 \mathrm{~m}^{3} \mathrm{~s}^{-1}$, respectively (Table 6). Although LH-simulated mean monthly flow was similar to observed values in most rivers, it was more variable than measured values for most rivers during the years 1981-2006 as indicated by the minimum and maximum monthly stream flows between compared data sets (Table 6).

\subsection{LH-simulated river discharge and its evaluation globally}

For the global land surface as a whole, LH-simulated longterm (1961-1990) mean annual surface runoff averaged $292 \mathrm{~mm}$, only $30 \mathrm{~mm}$ less than that $(322 \mathrm{~mm})$ in the Cogley (1998) annual runoff data. The standard deviation of LHsimulated mean annual surface runoff among 59199 grids cells was $438 \mathrm{~mm}$, almost equaling $442 \mathrm{~mm}$ from Cogley runoff data. The spatial patterns of LH-simulated mean annual surface runoff for the entire world visually agreed well with those of Cogly runoff data (Fig. 9a and b). For example, both data showed that mean annual surface runoff was less than $100 \mathrm{~mm}$ in most parts of the western China, central Asia, and the western US, where semi-arid and arid ecosystems dominate. In contrast, both data sets showed that mean annual surface runoff in the Amazon and Congo River basins, southeastern Asia, and the eastern part of North America were more than $500 \mathrm{~mm}$ (Fig. 9a and b).

The magnitudes of LH-simulated mean annual discharges for 10 large rivers worldwide were generally in good agreement with observed values for these rivers (Table 7). For example, LH-simulated mean annual discharge almost equaled (difference $<1 \%$ ) observed values for the Danube River in Europe, the Mackenzie River in North America, and the Amazon River in South America (Table 7). In addition, LHsimulated mean annual discharge was only $8 \%, 5 \%$, and $15 \%$ less than observed values for the Yenisei River in Russia, the Xi Jiang River and Chang Jiang River in China, respectively. It was only $6 \%$ higher than the observed value for the Mississippi River in the US. Large differences occurred for the Congo River and Blue Nile River in Africa, and the Murray River in Australia. For these large rivers, LH-simulated mean annual discharge was about $60 \%$ (for the two African rivers) and $199 \%$ higher (for the Murray River) than observed values, respectively (Table 7). LH also captured well $\left(R^{2}>0.37, p<0.01\right)$ interannual variations of river discharges for most large rivers, including the Mackenzie, Mississippi, Danube, Chang Jiang, Amazon, and Murray River (Fig. 10). When aggregated by $1^{\circ}$ latitudinal zones, LH-simulated mean annual surface runoff was in accordance with previously published data (Fig. 11), but LH slightly overestimated annual surface runoff between $0^{\circ} \mathrm{S}$ and $15^{\circ} \mathrm{S}$ latitudinal zones and underestimated it between $25^{\circ} \mathrm{N}$ and $35^{\circ} \mathrm{N}$ latitudinal zones. 

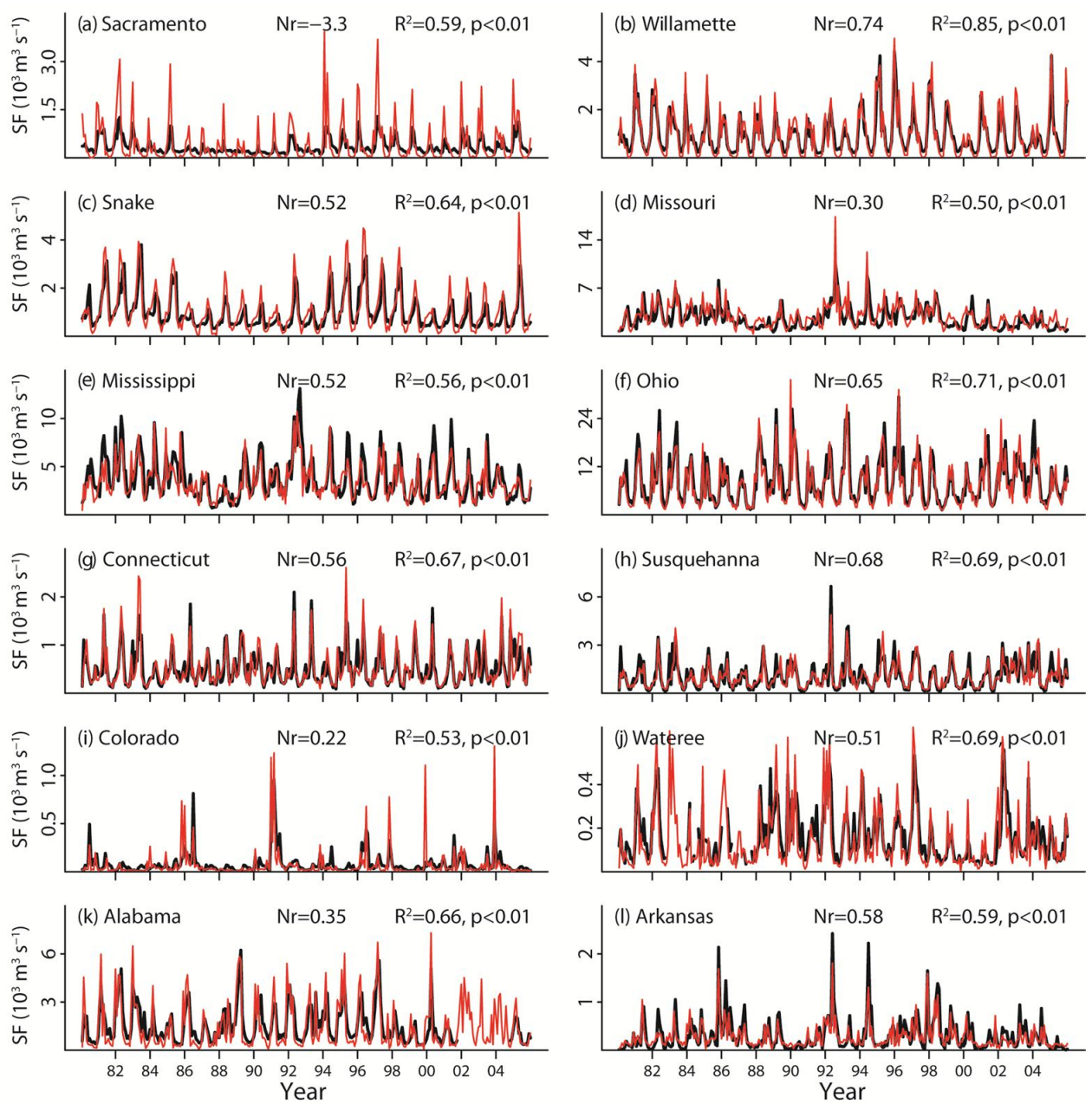

Fig. 8. Comparison between LH-simulated (red line) and US Geological Survey observed monthly stream flow (SF) (black line) at 12 river gage stations. $\mathrm{Nr}$ is the Nash-Sutcliffe coefficient.

Table 6. Comparison between LH-simulated and observed stream flow for 12 major rivers in the US.

\begin{tabular}{lrrr|rrr|r|rr}
\hline & \multicolumn{2}{c}{ USGS stream flow $\left(\mathrm{m}^{3} \mathrm{~s}^{-1}\right)$} & \multicolumn{2}{c}{ Simulated stream flow $\left(\mathrm{m}^{3} \mathrm{~s}^{-1}\right)$} & \multicolumn{3}{c}{ Statistics } \\
\cline { 2 - 9 } Rivers & $\min$ & $\max$ & $\operatorname{mean}$ & $\min$ & $\max$ & $\operatorname{mean}$ & $R^{2}$ & $\mathrm{Nr}^{\mathrm{b}}$ & $\Delta(\%)$ \\
\hline 1. Sacramento & 109.3 & 1288.4 & 346.6 & 2.1 & 3964.6 & 429.6 & 0.59 & -3.3 & 24.0 \\
2. Willamette & 195.4 & 4406.1 & 950.7 & 9.0 & 4872.7 & 951.0 & 0.85 & 0.74 & 0 \\
3. Snake & 276.5 & 3800.1 & 966.4 & 64.4 & 3796.7 & 985.5 & 0.64 & 0.52 & 2.0 \\
4. Missouri & 615.6 & 10655.6 & 2612.3 & 347.8 & 17298.3 & 2854.2 & 0.50 & 0.30 & 9.3 \\
5. Mississippi & 709.1 & 13107.9 & 3732.4 & 504.3 & 12184.6 & 3341.6 & 0.56 & 0.52 & -10.5 \\
6. Ohio & 1225.8 & 29421.2 & 8369.2 & 1227.3 & 33323.5 & 7561.8 & 0.71 & 0.65 & -9.6 \\
7. Connecticut & 88.4 & 2098.8 & 516.2 & 93.9 & 2658.4 & 532.5 & 0.67 & 0.56 & 3.2 \\
8. Susquehanna & 100.0 & 6657.3 & 1096.2 & 204.3 & 5068.9 & 1052.2 & 0.69 & 0.68 & -4.0 \\
9. Colorado & 7.2 & 957.1 & 79.9 & 1.8 & 1292.7 & 64.2 & 0.53 & 0.22 & -19.6 \\
10. Wateree & 29.9 & 559.0 & 156.1 & 1.8 & 667.6 & 144.3 & 0.69 & 0.51 & -7.5 \\
11. Alabama & 325.4 & 6232.0 & 1520.1 & 51.0 & 7369.6 & 1421.6 & 0.66 & 0.35 & -6.5 \\
12. Arkansas & 6.2 & 2422.5 & 305.3 & 19.6 & 1763.9 & 276.8 & 0.59 & 0.58 & -9.3 \\
\hline
\end{tabular}

a The observed monthly stream flow subtracted that from the Missouri River in model comparison.

b $\mathrm{Nr}$ refers to the Nash-Sutcliff coefficients. 
Table 7. Comparison between LH-simulated and observed annual discharges for 10 large rivers worldwide.

\begin{tabular}{lrr|rrr|rrr|r}
\hline & \multicolumn{2}{c|}{ Compare period } & \multicolumn{2}{c}{ Observed discharge $\left(\mathrm{m}^{3} \mathrm{~s}^{-1}\right)$} & \multicolumn{2}{|c|}{ Simulated discharge $\left(\mathrm{m}^{3} \mathrm{~s}^{-1}\right)$} & Diff $(\%)$ \\
\cline { 2 - 10 } Rivers & Fist year & Last year & $\min$ & $\max$ & $\operatorname{mean}$ & $\min$ & $\max$ & $\operatorname{mean}$ & \\
\hline 1. Danube & 1961 & 1984 & 5219 & 9293 & 6838 & 3314 & 9360 & 6790 & -1 \\
2. Congo & 1961 & 1983 & 34690 & 54964 & 43403 & 58385 & 97492 & 69723 & 61 \\
3. Murray & 1965 & 1984 & 36 & 1108 & 257 & 283 & 1826 & 769 & 199 \\
4. Yenisei & 1961 & 1984 & 11584 & 20966 & 17570 & 36 & 1108 & 16232 & -8 \\
5. Mississippi & 1961 & 1979 & 9884 & 25993 & 16574 & 9884 & 25993 & 17488 & 6 \\
6. Chang jiang & 1976 & 1979 & 23728 & 31770 & 25032 & 17000 & 26049 & 21255 & -15 \\
7. Xi jiang & 1976 & 1983 & 6607 & 8311 & 7085 & 5905 & 7977 & 6735 & -5 \\
8. Mackenzie & 1967 & 1984 & 7191 & 9662 & 8343 & 7433 & 10185 & 8436 & 1 \\
9. Amazon & 1972 & 1982 & 138608 & 176067 & 165615 & 145992 & 207499 & 176073 & 0 \\
10. Blue Nile & 1976 & 1990 & 805 & 2436 & 1528 & 1695 & 3344 & 2539 & 66 \\
\hline
\end{tabular}

\subsection{Results of two experimental simulations}

LH-simulated monthly stream flow in winter and early spring with the addition of radiation effect on snowmelt was closer than the degree-day method to observed values in the Snake, Missouri, Mississippi, Ohio, Connecticut, and Susquehanna watersheds (Fig. 12c-h). In these watersheds, heavy snow often occurs in winter and early spring. Because less snowmelt was simulated under the degree-day method in winter and early spring, the subsequent monthly stream flow was much higher than observed values in late spring in these watersheds where heavy snow occurs in winter and spring (Fig. 12ch). For the Alabama, Wateree and Colorado River (Fig. 12i$\mathrm{k}$ ), the simulated stream flows under the two approaches were almost identical because temperature is relatively high $\left(>0{ }^{\circ} \mathrm{C}\right)$ in winter and heavy snow rarely occurs in these watersheds.

LH-simulated annual ET under high $\mathrm{CO}_{2}$ concentration was about 30 to $75 \mathrm{~mm}$ lower than ET values simulated under low $\mathrm{CO}_{2}$ concentration in watersheds where forests are dominant land covers. The reason is because the higher $\mathrm{CO}_{2}$ concentration induced plant stomatal closure and thus decreased plant transpiration by a range of 33 to $73 \mathrm{~mm}$ in forest-dominated watersheds, such as the Connecticut and Susquehanna watersheds.

\section{Discussion}

Although model evaluation suggests LH performs well, much effort is still needed to improve the accuracy in simulating land-surface water balances. For example, LHsimulated monthly ET in summer was less than the Vörösmarty ET data in the Snake, Missouri, Mississippi and Arkansas watersheds (Fig. 3). In the Midwestern and western US, relative atmospheric humidity is comparatively lower than watersheds in the eastern and southern US. Actual ET is considered to increase as vapor-pressure deficit increases. Vörösmarty et al. (1998) considered the effects of relative hu-
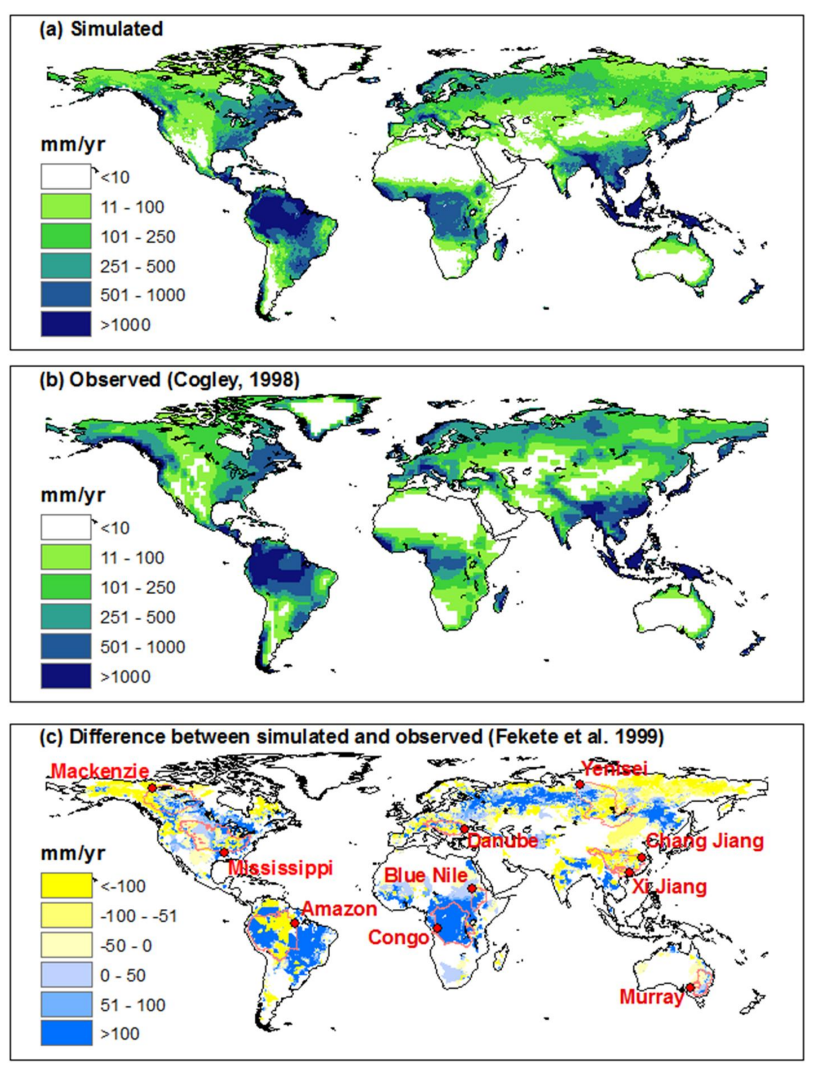

Fig. 9. Long-term mean annual surface runoff (mm): (a) LHsimulated runoff for the period 1961-1990, (b) observed runoff (Cogley, 1998) for different time periods, (c) difference between LH-simulated and Fekete et al. (1999) runoff data. The 10 large river watersheds in (c) were derived from HydroSHEDS data (Lehner et al., 2006). The geographic location of each gage station was based on Global River Discharge Database (RivDis2.0), available from http://www.sage.wisc.edu/riverdata/. For comparison, we regridded 1-degree Cogley runoff data onto simulated 0.5-degree grids using the nearest neighbor algorithm. 

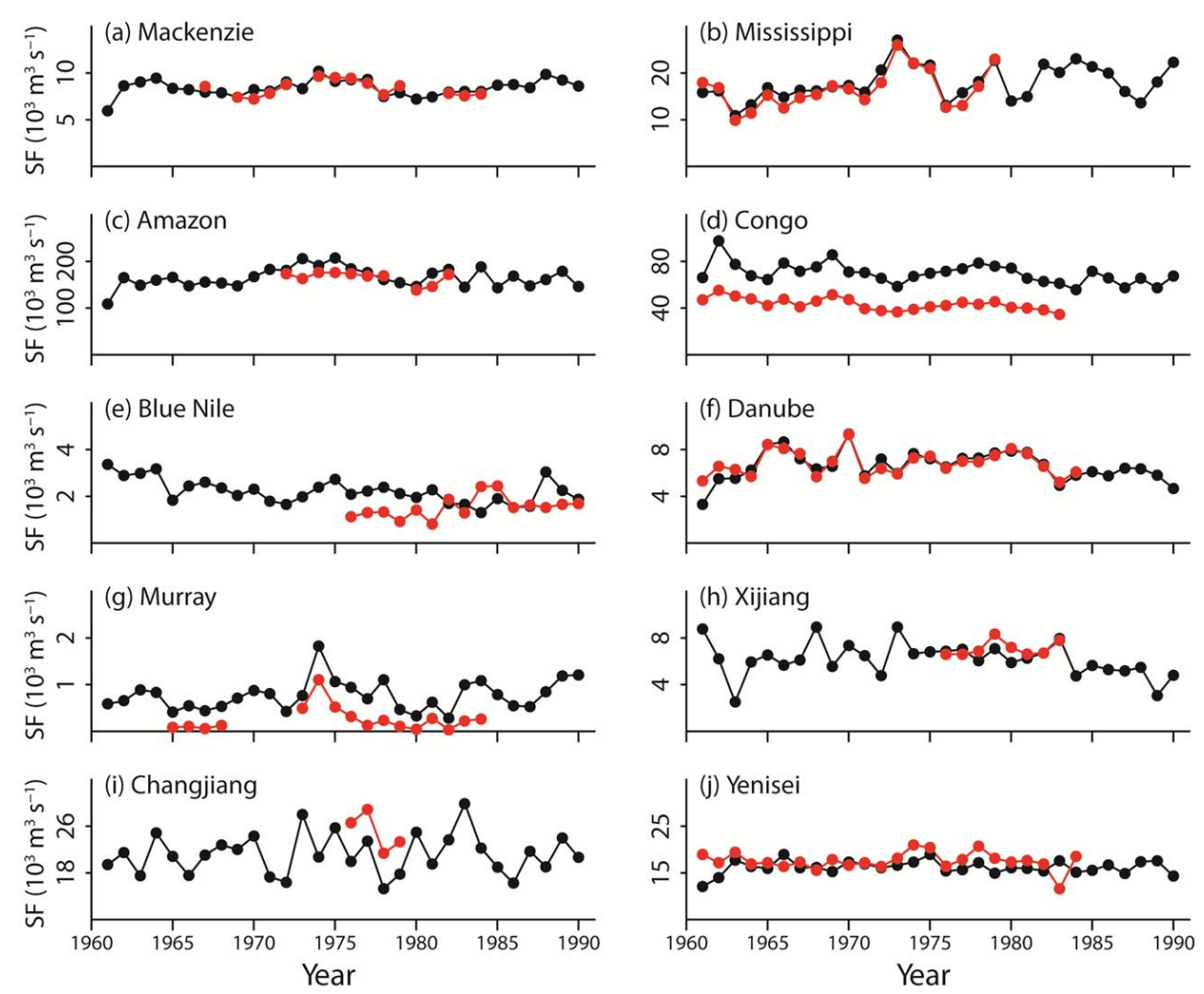

Fig. 10. Comparison between LH-simulated (black dotted line) and observed (red dotted line) annual discharges for 10 large rivers worldwide. The observed annual discharges are from RivDis2.0 database, available from http://www.sage.wisc.edu/riverdata/.

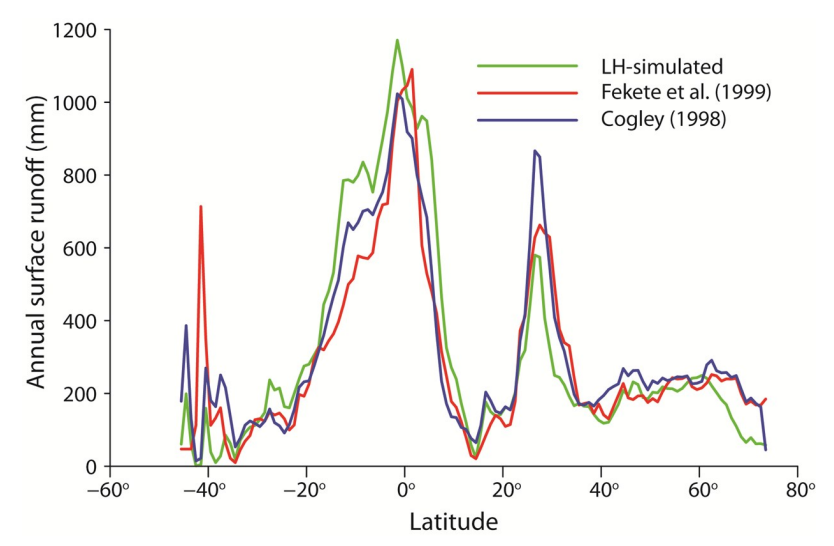

Fig. 11. Estimates of long-term mean annual surface runoff ( $\mathrm{mm})$, aggregated into 1-degree latitude zones. LH-simulated data are 30yr (1961-1990) long-term mean. The Cogley (1998) runoff data were at 1-degree land grid, and Fekete et al. (1999) runoff data were at 0.5-degree land grid.

midity and vapor pressure deficit on land surface hydrology. This explains why LH-simulated monthly ET in summer was smaller than Vörösmarty ET for those watersheds located in the Midwestern and western US. The consideration of rela- tive humidity and vapor-pressure deficit in Vörösmarty ET algorithm also contributed to the higher ET estimates in the Wateree and Alabama watersheds (Fig. 3j and k), in which water is not limited but annual mean temperature is high. In the Willamette River watershed, Vörösmarty ET peaked in April and then tended to decrease throughout the rest of year (Fig. 3b), resulting in lower ET simulation although water is not limited in this region. At its current stage, LH considers only radiative forcing while ignoring other meteorological effects on actual ET. Meteorological factors, such as relative humidity, play an important role in determining actual ET (Brunel et al., 2006; Rim et al., 2008), which suggests that they be considered in LH's future development.

LH-simulated soil moisture in the top $50 \mathrm{~cm}$ of the soil layer in US. Illinois and Iowa generally agreed well with observed values (Fig. 6). This good agreement indicated that LH has a strong ability to simulate soil moisture at the regional or even local scale. In addition, we suspect that the accuracy of input land covers, the 2.5 arc-min PRISM climate data, and the quality of STATSGO soil data, all contributed to the good agreement between simulated and observed soil moisture in these two regions. Illinois soil moisture was monitored at grass-covered sites across Illinois, an agricultural region (Hollinger and Isard, 1994). The GLCF data defines land covers in Illinois as a mix of grass and crops 

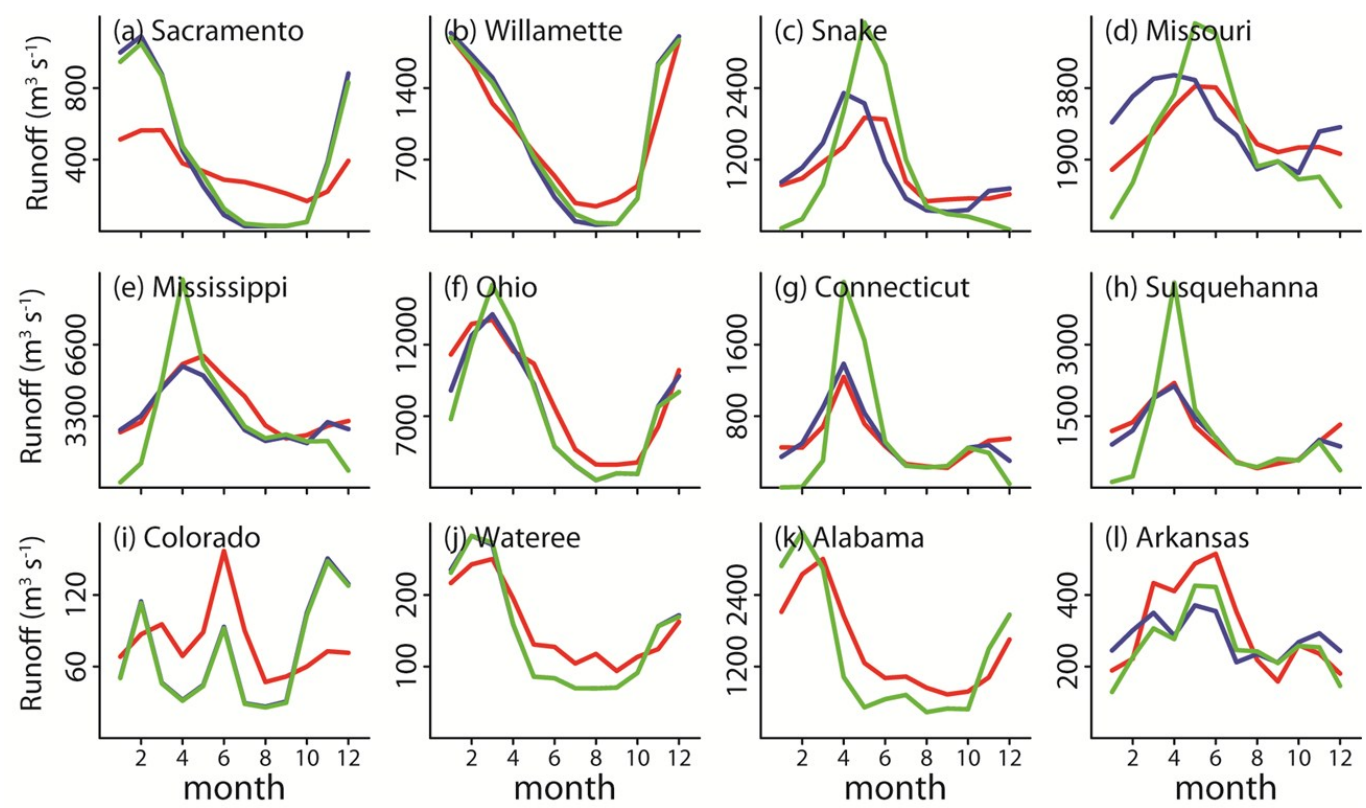

Fig. 12. Monthly river runoff simulated by LH (a) under the addition of solar radiation for snowmelt computation (blue line), and (b) using a degree-day method for snowmelt computation (green line), and (c) USGS observed average monthly runoff (red line) for 12 major rivers in the US.

(Supplement Fig. S3). Finer-scale climate data can better represent the spatiotemporal variation of climate across a region. Liu and Yang (2010) suggested that finer-scale climate data are likely to better capture the spatial variation of hydrological variables than those simulated at coarser resolution. Accurate spatial representation of soil moisture is difficult for large areas because it requires consideration of detailed soil attributes such as soil texture and its water holding capacity (Hollinger and Isard, 1994). The STATSGO soil texture data were created by generalizing more detailed soil survey maps and are often thought to be of high quality in representing soil characteristics in the US. Anderson et al. (2006) found that the hydrological simulation can be improved by combining detailed land cover with STATSGO soil data to refine model parameter estimates.

The good agreement between LH-simulated and observed stream flow for major rivers in the US (Fig. 8) and large rivers worldwide (Fig. 10) supports the utility and reliability of incorporating satellite data into LPJ-DGVM to simulate land surface water balances. The LH-simulated spatial pattern of mean annual surface runoff for the entire world was also visually remarkably similar to that captured by LPJDGVM (Fig. 2 in Gerten et al., 2004) because the core hydrologic components in two models are almost the same. On average, LH-simulated global long-term (1961-1990) mean annual surface runoff was $292 \mathrm{~mm}$, only $14 \mathrm{~mm}$ less than the LPJ-DGVM simulated runoff $(\approx 306 \mathrm{~mm}$ ) (Gerten et al., 2004). However, LH-simulated global mean annual surface runoff was much smaller than LPX-simulated surface runoff $(\approx 444 \mathrm{~mm})$, which tended to overestimate surface runoff magnitude in the tropics and throughout much of the Northern Hemisphere (Murray et al., 2011). Overall, LH captured well the global runoff distribution (Fig. 9a and b) although it over- and underestimated surface runoff in some areas when compared to observed data from Fekete et al. (1999) (Fig. 9c). For example, like LPJ-DGVM (Gerten et al., 2004), $\mathrm{LH}$ tended to underestimate surface runoff in subarctic regions. In addition, like LPJ-DGVM (Gerten et al., 2004) and LPX (Murray et al., 2011), LH represented well interannual variations in large river discharges (Fig. 10).

Vegetation and crops are far from static and have important effects on land surface water balance (Arora, 2002). Different vegetation and crops have varying physiological traits, such as LAI and stomatal conductance, affecting plant transpiration and soil evaporation due to changes in surface albedo. The accuracy of land cover and soil representation may cause LH-simulated water balances not to agree well with corresponding observed values. For example, LH-simulated ET in April of 1998 in the Florida Everglades decreased sharply relative to March and was much lower than the measured value (Fig. 4). Land covers in the Florida Everglades are mostly wetlands that never dry or dry only during parts of years (German, 2000). In contrast, LH (actually the GCLF data) defines land cover in this area as grassland. As a result, precipitation in April could be very low (average $14 \mathrm{~mm}$ ) while soil evaporation remains high resulting in a higher ET measurement, which suggests the accurate representation of 
land characteristics is required in applying $\mathrm{LH}$ at the small regional scale.

The type of land cover affects the accuracy of modeled land-surface water balances. LH better captured the magnitudes and variations of monthly stream flow in forestdominated watersheds relative to those watersheds dominated by crops, grassland, or shrubs (Table 6 and Supplement Fig. S3); largely because monthly precipitation was generally higher throughout the year and the hydrologic effects of human activities such as irrigation were comparatively lower in these watersheds. In contrast, for semi-arid and arid environments in the western US and other parts of the world, precipitation is thought to be important for controlling snow or rainfall dominated river hydrography. Excessive soil water may percolate into deep ground water and then discharge in valleys at lower elevations. As a result, actual river peak flow could be lower than LH-simulated flow, such as in the Colorado River through Texas (Fig. 8i).

Like LPJ-DGVM (Gerten et al., 2004), LH does not simulate human withdrawal of water from rivers and the reduction of river flow by human water consumption (e.g. Döll et al., 2003). It is not surprising, therefore, that the magnitudes of LH-simulated monthly stream flow were much higher than observed data for the Sacramento River (Fig. 8a). The Sacramento River watershed has been intensely developed for water supply and hydroelectric power generation. An earlier study (Yates et al., 2009) that considered consumptive and non-consumptive use of water in the Sacramento River watershed was able to correctly reproduce the water balance and river hydrology in the watershed. Likewise, both $\mathrm{LH}$ and LPJ-DGVM ignore evaporation loss from lakes, reservoirs, wetlands, and non-perennial ponds. These processes contributed to overestimation of discharges for large rivers, such as the Murray River and Blue Nile River, in arid regions (Fig. 10) (Gerten et al., 2004). The exclusion of water evaporation from river channels and potential underestimation of rainfall interception by tropic forest canopies (e.g. Murray et al., 2011) contributed LH-simulated river discharges to be higher than observed values for the Congo River in Africa (Fig. 10d). In addition, the difference between satellite-based land cover and the DGVM-simulated vegetation, the exclusion and inclusion of vegetation-related biogeochemical processes in the model's construction, and the setup of model running (e.g. the length of years used for spin-up simulation) can affect the agreement between LH- and LPJ-DGVMsimulated water balance in each basin. Further study is therefore required to explicitly examine how these differences affect simulated water balances.

Despite a number of discrepancies that emerged when comparing LH-simulated to observed values of three hydrologic values at different spatial scales, LH offers several advantages over the use of a standard DGVM for simulating regional or global land-surface hydrology. First, LH predefines land covers instead of simulating them as, for example, in LPJ-DGVM. This greatly simplifies LH's structure (Fig. 1) but does not reduce LH's ability to simulate land surface water balances. This simplification of model structure makes LH easier to grasp (e.g. Paola, 2011). Second, LH ignores some vegetation-related biogeographical and biogeochemical dynamics. Vegetation-related parameters (Tables 1 and 2) are reduced by more than half compared to those in LPJDGVM. The reduction of parameters makes LH easier to parameterize in practice. This in turn has potential to reduce the uncertainty of model results resulting from model parameterization (e.g. Zaehle et al., 2005; Wramneby et al., 2008). Third, the addition of solar radiation for snowmelt computation in LH greatly improved estimates of river stream flow in winter and early spring in snow-dominated watersheds (Fig. 12). Gerten et al. (2004) suggested that LPJ-DGVM tended to underestimate surface runoff in winter at high latitudes of the Northern Hemisphere. With the addition of the solar radiation effect on snowmelt, LH-simulated mean annual river discharges agreed well with observed values for the Mackenzie and Yenisei Rivers (Fig. 10a and j). Fourth, LH couples plant photosynthesis and phenology. It is therefore able to simulate the role of changes in atmospheric $\mathrm{CO}_{2}$ concentration in land-surface water balance (e.g. Leipprand and Gerten, 2006; Robock and Li, 2006). The coupling of plants photosynthesis and phenology is also crucial for studying effects of land cover change on the land-surface water balance because of the interactions between vegetation and water (e.g. Kergoat et al., 2002; Rost et al., 2008).

\section{Conclusions}

LH is developed by incorporating satellite-based land covers and proportional foliar vegetation covers into LPJ-DGVM (Sitch et al., 2003; Gerten et al., 2004) for simulating land surface water balances at the regional scale. LH's performance has been evaluated at different spatial scales using a compilation of existing data sets. This study concluded the following:

1. LH is able to accurately simulate ET, soil moisture, and surface runoff at the regional scale. The incorporation of satellite-based data into LH helps simplify the model's structure and thus makes LH easier to grasp. The reduction of model parameters enables LH easier to parameterize in practice than common DGVMs.

2. Compared to a degree-day method for snowmelt computation in LPJ-DGVM, LH considered the effects of both solar radiation and temperature on snowmelt. The addition of solar radiation for snowmelt computation improved LH's estimates of stream flow in winter and early spring for rivers at mid-to-high latitudes. The study suggested, therefore, that to better simulate surface runoff at mid-to-high latitudes, DGVMs should explicitly consider the effect of solar radiation on snowmelt. 
3. Hydrologic evaluation of $\mathrm{LH}$ at the regional scale indicated that it also has a strong ability to simulate regional scale land surface water balances, but accurate estimates of regional scale land surface hydrology require both LPJ-DGVM and LH to correctly and explicitly define the land characteristics. In addition, human-related factors such as water withdrawal and consumption, meteorological factors such as vapor pressure deficit, and the routing of water among simulated units should be considered in LH's future development.

\section{Supplementary material related to this article is available online at: http://www.hydrol-earth-syst-sci.net/ 16/2547/2012/hess-16-2547-2012-supplement.pdf.}

Acknowledgements. Research was supported by NSF EPSCoR grant (NSF Cooperative Agreement EPS-0814372), NSF grant number ATM 0602409, and the Department of Geography at the University of Oregon. We greatly appreciate all developers of the Lund-Potsdam-Jena (LPJ) dynamic global vegetation model, with special thanks to Dieter Gerten for developing the surface-hydrology model embedded in LPJ-DGVM. We thank three anonymous reviewers for their valuable comments on this study. We appreciate Sony Pradhanang for her discussion on USGS stream flow data.

Edited by: J. Liu

\section{References}

Anderson, R. M., Koren, V. I., and Reed, S. M.: Using SSURGO data to improve Sacramento Model a priori parameter estimates, J. Hydrol., 320, 103-116, 2006.

Arora, V.: The use of the aridity index to assess climate change effect on annual runoff, J. Hydrol., 265, 164-177, 2002.

Arora, V. and Boer, G.: The temporal variability of soil moisture and surface hydrological quantities in a climate model, J. Climate., 19, 5875-5888, 2006.

Betts, R. A., Boucher, O., Collins, M., Cox, P. M., Falloon, P. D., Gedney, G., Hemming, D. L., Huntingford, C., Jones, C. D., Sexton, D. M. H., and Webb, M. J.: Projected increase in continental runoff due to plant responses to increasing carbon dioxide, $\mathrm{Na}-$ ture, 448, 1037-1041, 2007.

Boegh, E., Thorsen, M., Butts, M. B., Hansen, S., Christiansen, J. S., Abrahamsen, P., Hasager, C. B., Jensen, N. O., van der Keur, P., Refsgaard, J. C., Schelde, K., Soegaard, H., and Thomsen, A.: Incorporating remote sensing data in physically based distributed agro-hydrological modeling, J. Hydrol., 287, 279-299, 2004.

Bowen, I. S.: The ratio of heat losses by conduction and by evapotranspiration from any water surface, Phys. Rev., 27, 779-787, 1926.

Brabson, B. B., Lister, D. H., Jones, P. D., and Palutikof, J. P.: Soil moisture and predicted spells of extreme temperatures in Britain, J. Geophys. Res., 110, D05104, doi:10.1029/2004JD005156, 2005.
Brovkin, V., van Bodegom, P. M., Kleinen, T., Wirth, C., Cornwell, W. K., Cornelissen, J. H. C., and Kattge, J.: Plant-driven variation in decomposition rates improves projections of global litter stock distribution, Biogeosciences, 9, 565-576, doi:10.5194/bg-9-5652012, 2012.

Brunel, J. P., Ihab, J., Droubi, A. M., and Samaan, S.: Energy budget and actual evapotranspiration of an arid oasis ecosystem: Palmyra (Syria), Agr. Water Manage., 84, 213-220, 2006.

Campo, L., Caparrini, F., and Castelli, F.: Use of multi-platform, multi-temporal remote-sensing data for calibration of a distributed hydrological model: an application in the Arno basin, Italy. Hydrol. Process., 20, 2693-2712, 2006.

Cogley, J. G.: GGHYDRO - Global Hydrographic Data, Release 2.2. Trent Climate Note 98-1. Department of Geography, Trent University, Peterborough, Ontario, Canada, 1998.

Daly, C., Taylor, G. H., Gibson, W. P., Parzybok, T. W., Johnson, G. L., and Pasteris, P.: High-quality spatial climate data sets for the United States and beyond, T. Am. Soc. Agri. Eng., 43, 19571962, 2000.

Daly, C., Gibson, W. P., Taylor, G. H., Johnson, G. L., and Pasteris, P.: A knowledge-based approach to the statistical mapping of climate, Clim. Res., 22, 99-113, 2002.

Döll, P., Kaspar, F., and Lehner, B.: A global hydrological model for deriving water availability indicators: model running and validation, J. Hydrol., 270, 105-134, 2003.

Engstrom, R., Hope, A., Kwon, H., Harazono, Y., Mano, M., and Oechel, W.: Modeling evapotranspiration in Arctic coastal plain ecosystems using a modified BIOME-BGC model, J. Geophys. Res-Biogeo., 111, G02021, doi:10.1029/2005JG000102, 2006.

Entin, J. K.: Spatial and temporal scales of soil moisture variations. Ph.D. dissertation, Department of Meteorology, University of Maryland, 125 pp. 1998.

Entin, J. K., Robock, A., Vinnikov, K. Y., Hollinger, S. E., Liu, S., and Namkhai, A.: Temporal and spatial scales of observed soil moisture variations in the extratropics, J. Geophys. Res., 105, 11865-11877, 2000.

Evans, S. and Trevisan, M.: A soil water-balance bucket model for paleoclimatic purposes. 1. model structure and validation, Ecol. Model., 82, 109-129, 1995.

Fekete, B. M., Vörösmarty, C. J., and Grabs, W.: Global composite runoff fields of observed river discharge and simulated water balances, Report No. 22, Global Runoff Data Centre, Koblenz, 1999.

Fekete, B. M., Vörösmarty, C. J., and Grabs, W.: High-resolution fields of global runoff fields of observed river discharge and simulated water balances, Global Biogeochem. Cy., 16, 1042, doi:10.1029/1999gb001254, 2002.

German, E. R.: Regional evaluation of evapotranspiration in the Everglades: US Geological Survey Investigations Report 00-4217, 48 pp., 2000.

Gerten, D., Schaphoff, S., Haberlandt, U., Lucht, W., and Sitch, S.: Terrestrial vegetation and water balance - hydrological evaluation of a dynamic global vegetation model, J. Hydrol., 286, 249270, 2004.

Glenn, E. P., Huete, A. R., Nagler, P. L., Hirschboeck, K. K., and Brown, P.: Integrating remote sensing and ground methods to estimate evapotranspiration, CRC Cr. Rev. Plant Sci., 26, 139-168, 2007. 
Hansen, M. C., DeFries, R. S., Townshend, J. R. G., and Sohlberg, R.: Global land cover classification at $1 \mathrm{~km}$ spatial resolution using a classification tree approach, Int. J. Remote Sens., 21, 13311364, 2000.

Hansen, M., DeFries, R. S., Townshend, J. R. G., Carroll, M., Dimiceli, C., and Sohlberg, R. A.: Global percent tree cover at a spatial resolution of 500 meters: first results of the MODIS vegetation continuous fields algorithm, Earth Interac., 7, 1-15, 2003.

Haxeltine, A. and Prentice, I. C.: BIOME3: An equilibrium biosphere model based on ecophysiological constraints, resource availability and competition among plant functional types, Global Biogeochem. Cy., 10, 693-709, 1996.

Hollinger, S. E. and Isard, S. A.: A soil moisture climatology of Illinois, J. Climate, 7, 822-833, 1994.

Huang, J., Van Den Dool, H. M., and Georgakakos, K. P.: Analysis of model-calculated soil moisture over the United States, 19311993, and applications to long-range temperature forecasts, J. Climate., 9, 1350-1362, 1996.

Kane, D. L., ASCE, M., Gieck, R. E., and Hinzman, L. D.: Snowmelt modeling at small Alaskan arctic watershed, J. Hydrol. Eng., 2, 204-210, 1997.

Kergoat, L.: A model for hydrological equilibrium of leaf area index on a global scale, J. Hydrol., 213, 268-286, 1998.

Kergoat, L., Lafont, S., Douville, H., Berthelot, B., Dedieu, G., Planton, S., and Royer, J. F.: Impact of doubled $\mathrm{CO}_{2}$ on globalscale leaf area index and evapotranspiration: Conflicting stomatal conductance and LAI responses, J. Geophys. Res.-Atmos., 107, 4808, doi:10.1029/2001JD001245, 2002.

Khan, S. I., Hong, Y., Wang, J., Yilmaz, K. K., Gourley, J. J., Adler, R. F., Brakenridge, G. R., Policelli, F., Habib, S., and Irwin, D.: Satellite Remote Sensing and Hydrologic Modeling for Flood Inundation Mapping in Lake Victoria Basin: Implications for Hydrologic Prediction in Ungauged Basins, IEEE T. Geosci. Remote., 49, 85-95, 2011.

Kosugi, Y. and Katsuyama, M.: Evapotranspiration over a Japanese cypress forest. II. Comparison of the eddy covariance and water budget methods, J. Hydrol., 334, 305-311, 2007.

Lehner, B., Verdin, K., and Jarvis, A.: HydroSHEDS Technical Documentation. World Wildlife Fund US, Washington, DC, available at: http://hydrosheds.cr.usgs.gov, 2006.

Leipprand, A. and Gerten, D.: Global effects of doubled atmospheric $\mathrm{CO}_{2}$ content on evapotranspiration, soil moisture and runoff under potential natural vegetation, Hydrolog. Sci. J., 51, 171-185, 2006.

Liu, J. and Yang, H.: Spatially explicit assessment of global consumptive water uses in cropland: Green and blue water, J. Hydrol., 384, 187-197, 2010.

Lu, J., Sun, G., McNulty, S. G., and Amatya, D. M.: Modeling actual evapotranspiration from forested watersheds across the Southeastern United States, J. Am. Water Resour. As., 39, 887896, 2003.

Manabe, S. and Delworth, T.: The temporal variability of soil wetness and its impact on climate, Climatic Change, 16, 185-192, 1990.

Miller, D. A. and White, R. A.: A conterminous United States multilayer soil characteristics dataset for regional climate and hydrology modeling, Earth Interact., 2, 1-26, 1998.

Milly, P. C. D. and Shmakin, A. B.: Global modeling of land water and energy balances. Part I: the land dynamics (LaD) model, J.
Hydrometeorol., 3, 283-299, 2002.

Mitchell, T. D. and Jones, P. D.: An improved method of constructing a database of monthly climate observations and associated high-resolution grids, Int. J. Climatol., 25, 693-712, 2005.

Montzka, C., Canty, M., Kunkel, R., Menz, G., Vereecken, H., and Wendland, F.: Modelling the water balance of a mesoscale catchment basin using remotely sensed land cover data, J. Hydrol., 353, 322-334, 2008.

Moriasi, D. N., Arnold, J. G., Van Liew, M. W., Bingner, R. L., Harmel, R. D., and Veith, T. L.: Model Evaluation Guidelines for Systematic Quantification of Accuracy in Watershed Simulations, T. ASABE, 50, 885-900, 2007.

Müller, C., Bondeau, A., Lotze-Campen, H., Cramer, W., and Lucht, W.: Comparative impact of climatic and nonclimatic factors on global terrestrial carbon and water cycles, Global Biogeochem. Cy., 20, GB4015, doi:10.1029/2006GB002742, 2006.

Murphy, S. and Lodge, G.: Surface soil water dynamics in pastures in northern New South Wales. 1. Use of electrical resistance sensors, Aust. J. Exp. Agr., 44, 273-281, 2004.

Murray, S. J., Foster, P. N., and Prentice, I. C.: Evaluation of global continental hydrology as simulated by the Land-surface Processes and eXchanges Dynamic Global Vegetation Model, Hydrol. Earth Syst. Sci., 15, 91-105, doi:10.5194/hess-15-91-2011, 2011.

Nash, J. E. and Sutcliffe J. V.: River flow forecasting through conceptual models part I - A discussion of principles, J. Hydrol., 10, 282-290, 1970.

O’Donnell, G. M., Czajkowski, K. P., Dubayah, R. O., and Lettenmaier, D. P.: Macroscale hydrological modeling using remotely sensed inputs: Application to the Ohio River basin, J. Geophys. Res.-Atmos., 105, 12499-12516, 2000.

Paola, C.: Simplicity versus complexity, Nature, 469, 38-39, 2011.

Reich, P. B., Walters, M. B., Ellsworth, D. S., Vose, J. M., Volin, J. C., Gresham, C., and Bowman W. D.: Relationships of leaf dark respirations to leaf nitrogen, specific leaf area and leaf life-span: a test across biomes and functional groups, Oecologia, 114, 471482, 1998.

Rim, C. S.: Estimating evapotranspiration from small watersheds using a water and energy balance approach, Hydrol. Process., 22, 703-714, 2008.

Robock, A. and Li, H.: Solar dimming and $\mathrm{CO}_{2}$ effects on soil moisture trends, Geophys. Res. Lett., 33, L20708, doi:10.1029/2006GL027585, 2006.

Robock, A., Vinnikov, K. Y., Srinivasan, G., Entin, J. K., Hollinger, S. E., Speranskaya, N. A., Liu, S., and Namkhai, A.: The Global Soil Moisture Data Bank, B. Am. Meteorol. Soc., 81, 12811299, 2000.

Rost, S., Gerten, D., Bondeau, A., Lucht, W., Rohwer, J., and Schaphoff, S.: Agricultural green and blue water consumption and its influence on the global water system, Water Resour. Res., 44, W09405, doi:10.1029/2007WR006331, 2008.

Schlesinger, M. E. and Malyshev, S.: Changes in near-surface temperature and sea level for the Post-SRES $\mathrm{CO}_{2}$-stabilization scenarios, Integrat. Ass., 2, 95-110, 2001.

Shukla, J. and Mintz, Y.: Influence of land-surface evapotranspiration on earth's climate, Science, 215, 1498-1501, 1982.

Sitch, S., Smith, B., Prentice, I. C., Arneth, A., Bondeau, A., Cramer, W., Kaplan, J. O., Levis, S., Lucht, W., Sykes, M. T., Thonicke, K., and Venevsky, S.: Evaluation of ecosystem dynam- 
ics, plant geography and terrestrial carbon cycling in the LPJ Dynamic Global Vegetation Model, Glob. Change Biol. 9, 161-185, 2003.

Smith, B., Prentice, I. C., and Sykes, M. T.: Representation of vegetation dynamics in the modeling of terrestrial ecosystems: comparing two contrasting approaches within European climate space, Global Ecol. Biogeogr., 10, 621-637, 2001.

Tang, G. and Beckage, B.: Projecting the distribution of forests in New England in response to climate change, Divers. Distrib., 16, 144-158, 2010.

Vörösmarty, C. J., Federer, C. A., and Schloss, A. L.: Potential evaporation functions compared on US watersheds: Possible implications for global-scale water balance and terrestrial ecosystem modeling, J. Hydrol., 207, 147-169, 1998.
Wramneby, A., Smith, B., Zaehle, S., and Sykes, M. T.: Parameter uncertainties in the modeling of vegetation dynamics - Effects of on tree community structure and ecosystem functioning in European forest biomes, Ecol. Model., 216, 277-290, 2008.

Yates, D., Purkey, D., Sieber, J., Huber-Lee, A., Galbraith, H., West, J., Herrod-Julius, S., Young, C., Joyce, B., and Rayej, M.: Climate Driven Water Resources Model of the Sacramento Basin, California. J. Water Res. Pl-ASCE, 1355, 303-313, 2009.

Zaehle, S., Sitch, S., Smith, B., and Hatterman, F.: Effects of parameter uncertainties on the modeling of terrestrial biosphere dynamics, Global Biogeochem. Cy., 19, GB3020, doi:10.1029/2004GB002395, 2005. 